\title{
Akademisyenlerin İşlerini Anlamlı Kılan Faktörlere İlişkin Görüşleri*
}

\section{The Opinions of the Academicians on the Factors Make Their Work Meaningful}

\begin{abstract}
Ali BALCI**, İnci ÖZTÜRK***, Filiz AKAR****
Öz: İşgörenlerin iş yapma biçimleri, örgütten beklentileri, ihtiyaçları, kariyer anlayışları günden güne değişmektedir. İşgörenler yaptıkları işlerde amaç ve anlam aramaktadırlar. Bu bağlamda bu çalışmanın amacı, görece biri büyük ölçüde kurumsallaşmış (Ankara Üniversitesi), biri kısmen kurumsallaşmış (Yüzüncü Yıl Üniversitesi), diğeri de kurumsallaşmanın başlarında olan (Pamukkale Üniversitesi) üniversitelerde görev yapan öğretim üyelerinin işlerini anlamlı kılan faktörlere ilişkin görüşlerini tespit etmektir. Bu çalışma, "karma araştırma" deseninde gerçekleştirilen bir projenin nitel boyutunu konu edinmektedir. Araştırmanın verileri, "maksimum çeşitlilik" örnekleme yöntemiyle seçilen, sözü edilen üç üniversitenin İktisadî ve İdarî Bilimler/Siyasal Bilgiler, Mühendislik, Tıp ve Eğitim/Eğitim Bilimleri Fakültelerinde görev yapan 36 öğretim üyesinden yarı yapılandırılmış görüşme formuyla toplanmıştır. Verilerin analizinde içerik analizi yöntemi kullanılmıştır. Bulgulara göre; çalışma-iş yapma, öğretim üyeleri için hayatlarını idame ettirme anlamına gelmektedir. Öğretim üyelerine göre, öğretim üyeliğinin anlamlı yanları, bireysel gelişim ve öğretim işlevi iken öğretim üyeliğinin anlamsız yanı angarya olarak görülen idarî işlerdir. İşi anlamlı kılan görece en önemli örgütsel faktör örgütsel destek iken işi anlamsız k1lan en önemli örgütsel faktör, şartların yetersizliğidir. Öğretim üyelerinin iş yoğunluğu, iş-yaşam dengesi kurmalarını zorlaştırmaktadır. Öğretim üyeleri, danışmanlık yaparak ve bilgilerini paylaşarak topluma katk1 sunmaktadır.
\end{abstract}

Anahtar Kelimeler: Anlamlı iş, çalışmanın anlamı, iş-yaşam dengesi, akademisyen, nitel araştırma

Abstract: Ways of doing work, expectations from the organization, needs, career insights of employees, are changing day by day. Employees are looking for purpose and meaning in their work. In this context, the aim of this study is to determine the opinions of the faculty members on the factors make their work meaningful who work relatively institutionalized (Ankara University), partially institutionalized (Yüzüncü Yıl University) and the other (Pamukkale University) which is at the beginning of institutionalization. This study focuses on the qualitative research dimension of a project which was carried out as a mixed research design. The data needed for the study were collected from 36 faculty members in the Faculties of Economics and Administrative Sciences/Political Sciences, Engineering, Medical and Education/Educational Sciences of the three universities chosen by the maximum variation sampling method. Data were collected through semi-structured interview form. Content analysis method was used to analyze the qualitative data. According to the findings; working-doing business means to maintain their lives for faculty members. According to faculty members, the meaningful aspects of being a faculty member are individual development and teaching functions, while the meaningless aspect of being a faculty member is administrative affairs. The most important organizational factor that makes work meaningful is organizational support, while the most important organizational factor that makes the work meaningless is the inadequacy of the conditions. The workload of the faculty members makes it

\footnotetext{
*Bu makale, Prof. Dr. Ali Balcı yürütücülüğünde yapılan "Akademisyenlerin İşlerini Anlamlı Bulma Düzeyleri ve Anlamlı İşi Etkileyen Örgütsel Faktörler" adlı projeden üretilmiştir.

**Prof. Dr., Ankara Üniversitesi, Eğitim Bilimleri Fakültesi, Ankara-Türkiye, ORCID: 0000-0003-2025-3796, eposta: abalc29@gmail.com

***Arş. Gör. Dr., Ankara Üniversitesi, Eğitim Bilimleri Fakültesi, Ankara-Türkiye, ORCID: 0000-0001-9177-2038, e-posta: iiozturk@yahoo.com.tr

****Dr. Öğr. Üyesi, Bozok Üniversitesi, Eğitim Fakültesi, Yozgat-Türkiye, ORCID: 0000-0002-1597-580X, e-posta: cologne@gmail.com
} 
difficult for them to establish a work-life balance. Faculty members contribute to society by consulting and sharing their knowledge.

Keywords: Meaningful work, meaning of work, work-life balance, academician, qualitative research

\section{Giriş}

Örgütler, insanların sadece para kazandıkları yerler olmayıp günlük yaşamlarının önemli bir kısmını geçirdikleri mekân, ilişki, ruhsal atmosfer örüntüsü olarak görülmelidir. Zira örgütler, sadece iş doyumunun değil; yaşam doyumunun da karşılanmasının beklendiği mekânlardır. İşgörenlere, maddî kazanç ve ödüllerden çok onların kişisel ve meslekî gelişimlerini destekleyici, hedef ve amaçlarını gerçekleştirebilecekleri heyecan verici iş olanakları sunmanın, huzurlu, adaletli ve özgür bir çalışma ortamı sağlamaya bağlı olduğuna ilişkin birçok görüş bulunmaktadır (Fang Li ve Devos, 2008; Luecke, 2009). 1990'lı y1llardan itibaren işgören yapısındaki değişimler, etik skandallarla işgörenlerin örgütlerine duydukları güvenin azalması, hızlı rekabet koşullarında çalışmanın getirdiği tükenmişlik ve aidiyet sorunları, çalışanların sık iş değiştirmesi, anlamlı iş kavramının ortaya çıkışına zemin hazırlamıştır (Darling ve Chalofsky, 2004). Chalofsky ve Krishna (2009, s. 194), anlamı, bir "değer" olarak açıklamakta; anlamlı işi de kişinin işini icra ederken işini yapmış ve başarmış olmaktan sağladığı derin doyum ve görevini icra etmeye yönelik içsel güdüleyici olarak tanımlamaktadırlar.Alanyazında anlamlı iş; bireylerin yaşamlarını, amaçlılık ve katkı duygusu ile psikolojik, ruhsal ve sosyal doyum sağladıkları şeyleri yaparak yaşayabilme kabiliyeti (Miller, 2008), üst düzey bir rehberlik hissi aracılığıyla içten gelen, kişiyi bir şeyi yapmaya çağıran iş (Treadgold, 1997), işin amaç ve hedeflerinin, bireylerin kendi idealleri ve standartlarına göre değeri (May, Gilson ve Harter, 2004), bireyin işinde anlam arama arzusu (Lip-Wierissima ve Morris, 2009, s. 492) olarak çeşitli şekillerde tanımlanmaktadır.

Anlamlı iş çalışmalarının öncüsü olan Chalofsky'e (2003, s. 77) göre anlamlı iş, "benlik- kendilik anlayışı", "işin kendisi anlayışı", "denge anlayışı" olmak üzere üç temadan oluşan ve "kişiyi yaşamında bütünlüğe ulaştıran"(integrated wholeness) psikolojik bir yapıdır. Bu konuda çalışmalar yapan Miller (2008, s. 93) ise bu üç temaya "katkı anlayışı" temasını ekleyerek anlamlı işi dört temada ele almıştır. Bu dört temanın bir araya gelmesi, kişinin yaşamında bütünlüğe ulaşmasını sağlamaktadır. Maslow (1943) ise motivasyon kuramının temel taşlarından birisinin birleşmiş bütünlük olduğunu, bireyin, seçimleri ve işi de kapsayan etkinlikleriyle, doğuştan kapasitesini kullanarak kendini gerçekleştirmeye (self actualization) dönük bir içsel motivasyon taşıdığını, bu motivasyonun kişinin kendini tamamlamaya dönük bir motivasyon olduğunu belirtmiş̦tir (akt., Miller, 2008, s. 94).

Anlamlı işin boyutlarından olan "benlik- kendilik anlayışı", kişinin işine kendini verebilme düzeyine bağlı olarak işinde anlamı başarabilme kabiliyetidir (Loscocco, 1995, Akt. Chalofsky, 2003, s. 75). "İşin kendisi anlayışı" ya da "iş anlayışı" alanyazında Csikszentmihalyi'nin "akış" kavramı ile de açıklanmaktadır. Yüksek performans gösterenlerle yaptığı araştırma sonunda "akış" kavramını ortaya koyan Csikszentmihalyi'ye (2001, s. 5) göre birey, akışta iken tamamıyla kendini işe verme hissi yaşar. "İşin kendisi anlayışı", işi başarmış olma anlamı taşımaz; aksine işi yapıyor olma, o işte performans sergiliyor olma işgören için yoğun haz verici bir süreçtir. Chalofsky'e (2010) göre "denge anlayışı"; olgun bir yetişkinin, iş yaşamını bir macera, bir keşif olarak görmesidir.Birey, işi, kariyeri ve yaşamı arasındaki akışı düzenleyebilmekte, gerektiğinde risk alabilmekte olup esnektir.Birey, ilerleme ihtiyacı ile kontrol ihtiyacı arasındaki gerilimi yönetebilmektedir. Miller (2008, s. 31) tarafından Chalofsky'nin (2003) üç temasına tamamlayıcı dördüncü tema olarak eklenen "katkı anlayışı", kişinin kendinden başka kişilere, aidiyet hissettiği daha büyük bir gruba ya da evrene, bir misyon doğrultusunda hizmet etme, yarar sağlama arzusu olarak açıklanabilir.

Anlamlı işe ilişkin çeşitli modeller geliştirilmiştir. England ve Whitley'in (1990) "anlamlı iş yaşantısı" modeli;bir kişinin hayatında çalışmanın öneminin derecesini ifade eden "iş odaklılık", çalışılmak istenen iş çevresine ve ilişki niteliğine ilişkin şartları içeren "iş amaçları" ve bireyin, anlamlı bir işi yürütme yükümlülüğü ile işine değer vermesi gerekliliğine ilişkin "toplumsal norm" bileşenlerinden oluşmaktadır. Terez'in (2000) "anlamlı iş çevresi 
oluşturma ve ruhsal alan" modeline göre kişilerin işlerini anlamlı bulacakları iş çevresi yaratılmalıdır. Çünkü iş çevresi, sadece fiziksel olarak var olunan bir alan/uzay olmayıp kişilerin hem fiziksel hem de ruhsal ve davranışsal alanıdır. Bu alan; kişileri, yeteneklerini işinde kullanan işgörenlere dönüştürebilmelidir. Bu model misyon, insana saygı, gelişme, toplulukla diyalog kurabilme ve özbenlik olmak üzere beş anahtar öğeden oluşmaktadır. Rosso, Dekas ve Wrzesniewski'nin (2010) "anlamlı işin dört temel yolu" modeline göre anlamlı işin kaynakları, değerler, motivasyon ve inançlardan oluşan "benlik-kendilik"; iş arkadaşları, liderler, gruplar, topluluklar ve aileden oluşan "diğerleri"; işe bağlı görevlerin tasarımı, örgütsel misyon, finansal bağlam, iş-dışı yaşam, ulusal kültürden oluşan "iş bağlamı"kaynağ 1 vekişinin hissettiği ruhsallık olan "ruhsal yaşam" dır. Modele göre; kişinin değerli olarak tanımlayıp ayırt ettiği "bireyleşme", kişinin kendinden daha geniş bir bütüne ilişkin yaptığı hizmetler aracilı̆̆ıyla algıladığ 1 "katkı", kişinin kendisiyle sıkı bir uyum içinde gördügü eylemlerle anlamlı bulduğu "benlikle bağlantı" ve kişinin diğerlerinin var oluşları, ilkeleriyle uyum içinde olan eylemleriyle deneyimlediği "birleşim" olmak üzere dört yolla anlamlı iş yaşantısı oluşmakta ve sürmektedir.

Anlamlı iş, alanyazında en çok iş doyumu, kurumsal bağlılık, iş motivasyonu değişkenleriyle ilişkisi açısından incelenmektedir. Buna göre işini anlamlı bulma ile üst düzey performans göstererek işini yapmaya motive olma arasında olumlu yönde bir ilişki bulunmaktadır. Kişinin iş amaçları ve işle ilgili değerleri, çalışma yaşamındaki değerlerin bir yansıması olarak algilanmaktadır (Ros, Schwartz ve Surkiss, 1999). Brown, Kitchell, O'Neill, Lockliear, Vosler, Kubek ve Dale'nin (2001) belirttiğine göre anlamlı iş yaşantısı içinde olan işgörenlerin, işlerini yaparken kendiliğinden doğal bir doyum hissi yaşadıkları ortaya konulmuştur. Lair ve Wieland'a (2012) göre örgütteki iletişim, işi anlamlı bulmayı şekillendirmekte; âdeta sosyal bir kurumsal yapı rolünü oynamaktadır. McClure ve Brown'a (2008) göre, güçlü bir bağl1lık duygusu hissetmektemel altı bileşenden oluşur: Bunlar yapılan işin içinde benliğini/kendini bulma, birlikte çalışllan toplulukta birlikte öğrenme sürecine dâhil olma ve grubun bir parçası olarak davet edilme, anlamlı bir iş yapıyor olma duygusu taşıma, kabul edilme ve tanınma-takdir edilme, kişilerarası ilişkilerde kendini gerçekleştirme ve yansitabilmedir.

Alanyazın incelendiğinde, anlamlı iş yaşantısı olan kişilerin stres ve depresyonla negatif, benlik kavramları ile pozitif ilişkilerinin olduğu; anlamlı iş bağlılığı olan katılımcıların, daha çok probleme odaklı başa çıkma yoluna yöneldikleri (Treadgold, 1997); yaşamda ruhsal bir perspektife sahip olmanın, hayatta anlam ve amaçların yaratılmasına yardım ettiği (Mohan ve Uys, 2006); olumlu anlamlı işin zihinsel sağlı̆̆ olumlu etkilediği (Arnold, Turner, Barling, Kelloway ve McKee, 2007) bulgularına ulaşılmıştır. Ruhsal açıdan düşünüldüğünde iş, sadece ilginç ya da zorlayıcı olma gibi özelliklere sahip değildir; iş, daha derin anlam ve amaç arayışı, bireyin hayalini yaşaması, bireyin işin anlamını araştırarak ve diğerlerine katkı sağlayarak içsel dünyasını ifade etmesi gibi durumlar çalışma yerinde ruhsal büyüme olarak adlandırılmaktadır (Graber ve Johnson, 2001). Daha derin anlam ve amaç arayışının akademisyenlik mesleğinde yaşandığı söylenebilir. Bir üniversitede çalışma yerinde ruhsal büyümeyi sağlayan faktörler arasında öğrenciler ile etkileşim, ders işleme ve öğrencilerden gelen dönütler sayılabilir (Mat, Romli, Mat ve Noor, 2012, s. 163).

Bunların dışında,örgütün kimliği, finansal kazançları, bağımsız karar verebilme, karşılıklı sayg1 ve yaratıcılık için sunulan olanakların, değer verilen kişilerarası ilişkileri iş ortamında kurma ve iş dışında da bu iliş̧ileri sürdürebilmenin, işgörenlerin işlerini anlamlı bulmalarını ve iş doyumlarını sağlayan faktörler arasında yer aldığı bulunmuştur (Brown ve diğerleri, 2001).

Türkiye'de alanyazında anlamlı iş ile ilgili olarak yapılan çalışmalar incelendiğinde, akademisyenler üzerinde yapılan bütüncül bir çalışmaya rastlanmamıştır. Alanyazında, daha çok öğretmenler üzerinde yapılan çalışmalara rastlanmıştır. Ampirik çalışma olarak Toptaş'ın (2016) ilkokul öğretmenleri üzerinde yaptı̆̆ öğretmenlerin işlerini anlamlı bulma düzeyleri ve işlerini anlamlı bulmalarını etkileyen faktörleri ortaya koyduğu çalışması bulunmaktadır. Yukarıda sayılanların dışında, anlamlı işin kavranmasına yardımcı olan iş-yaşam dengesi (Mustafayeva ve Bayraktaroğlu, 2014; Negiz ve Tokmakç1, 2011; Öztan ve Doğan, 2015; 
Poyraz, 2013), topluma katkı (Beldăg, Yaylac1, Gök ve İpek, 2015; Yücel ve Atl1, 2014), akademik özgürlük (Bozkurt, 2012; Gedikoğlu, 2013; Öztürk, 2006), örgütsel destek (Erat, Erdil, Kitapçı ve Çömlek, 2012; Kasalak ve Bilgin Aksu, 2014), iş yükü (Apaydın, 2012; Ergöl, Koç, Eroğlu ve Taşkın, 2012; Kahraman ve Çelik, 2015) gibi konularda akademisyenler üzerine çeşitli çalışmalar yapılmıştır.

Bu çalışmanın amacı, görece biri büyük ölçüde kurumsallaşmış (Ankara Üniversitesi), biri kısmen kurumsallaşmış (Yüzüncü Yı1 Üniversitesi), diğeri de kurumsallaşmanın başlarında olan (Pamukkale Üniversitesi) üç üniversiteninİktisadî ve İdarî Bilimler/Siyasal Bilgiler, Mühendislik, Tıp ve Eğitim/Eğitim Bilimleri Fakülteleri öğretim üyelerinin işlerini ne düzeyde ve niçin anlamlı bulduklarını tespit etmektir. $\mathrm{Bu}$ ana amaç doğrultusundaaraştırmanın alt amaçları aşağıda yer almaktadır:

1) Çalışmak öğretim üyeleri için ne anlama gelmektedir?

2) Öğretim üyelerinin yaptıkları işin anlamlı veanlamsız tarafları ile ilgili görüşleri nelerdir?

3) Öğretim üyelerinin yaptıkları işi anlamlı kılan ve kılmayan başlıca örgütsel faktörlere ilişkin görüşleri nelerdir?

4) Öğretim üyelerinin, iş-yaşam dengesine ilişkin görüşleri nelerdir?

5) Öğretim üyelerinin yaptıkları iş kendilerine ve çevrelerine nasıl bir katkı sağlamaktadır?

\section{Yöntem}

Öğretim üyelerinin işlerini ne düzeyde ve niçin anlamlı bulduklarını tespit etmeyi ortaya koymayı hedefleyen bu araştırmada, nitel araştırma desenlerinden fenomenoloji kullanılmıştır. Araştırmanın çalışma grubunu oluşturan öğretim üyelerinin görev yaptıkları üniversiteler, kuruluş yıllarına göre seçilmiştir.Araştırmanın çalışma grubunu görece büyük ölçüde kurumsallaşmış olan Ankara Üniversitesinin, görece kısmen kurumsallaşmış olan Yüzüncü Yı1 Üniversitesinin ve henüz kurumsallaşmanın başında olan Pamukkale Üniversitesinin Eğitim/Eğitim Bilimleri, İktisadî ve İdarî Bilimler, Tıp ve Mühendislik Fakültelerinden birer doktor öğretim üyesinin, birer doçentin ve birer profesörün araştırmaya dâhil edilmesiyle toplamda 36 öğretim üyesi oluşturmuştur. Araştırmanın ihtiyaç duyduğu kaynak kişiler, "maksimum çeşitlilik örnekleme" yöntemi ile gönüllülük esasına göre seçilmiştir. Veriler 2015 yılının Mart ve Nisan aylarında toplanmıştır.

\section{Veri toplama}

Araştırmada veri toplama aracı olarak yarı yapılandırılmış görüşme formu kullanılmıştır. Görüşme formu, projenin nicel aşamasında geliştirilen Anlamlı İş Ölçeğindeki maddeler ve boyutlardan yararlanılarak hazırlanmıştır.Taslak görüşme formu, kapsam geçerliği için alan ve dil uzmanlarının görüşüne sunulmuş; sonra iki öğretim üyesi üzerinde sınanmıştır. Bu işlemler sonrası görüşme formuna son şekli verilmiştir. Katılımcı öğretim üyeleriyle yüzyüze yapılan görüşmeler, katılımcılarınizni alınarak ses kaydı ya da not alma işlemi ile kaydedilmiştir. Daha sonra ses kayıtları deşifre edilerek metne dönüştürülmüştür. Nitel verilerin analizinde iseiçerik analizi yöntemi kullanılmıştır. Araştırmacılar, geçerlik ve güvenirlik kapsamında, farklı katılımcı gruplarından çeşitli deneyimler elde etmek amacıyla veri çeşitlemesi yapmış; çelişkili ve şüpheli veri elde edilmesini önlemek amacıyla tekrarlı sorgulamalar yapmış ve verilere ilişskin kavrayışı ve yorumları derinleştirmek amacıyla kısa aralıklı toplantılar yapmışlardır (Shenton, 2004).

\section{Bulgular}

İçerik analizi sonucunda anlamlı iş ile ilgili görüşler, "çalışmanın anlamı", "işin anlamlı tarafları", "işi anlamlı kılan/kılmayan örgütsel faktörler", "iş-yaşam dengesi”" ve "işin bireyin kendisine ve başkalarına katkı sağlaması” olmak üzere beş tema altında toplanmıştır. 


\section{Çalışmanın anlamı}

Çalışmanın anlamı temasına ilişkin yanıtlar; "fayda/katkı sağlama", "iş odaklı olma" ve "var oluş çabası" olmak üzere üç kategoride toplanmaktadır. Her bir kategorinin de alt kategorileri bulunmaktadır. Frekanslarına göre bu kategoriler, çoktan aza doğru "fayda/katkı sağlama $(\mathrm{n}=58)$ ", "var oluş çabası $(\mathrm{n}=20) "$ ve "iş odaklı olma $(\mathrm{n}=6)$ " şeklinde sıralanmaktadır. Çalışmanın anlamı temasına ilişkin kategoriler Tablo 1, Tablo 2 ve Tablo 3 'te verilmiştir.

Tablo 1.

Çalışmanın Anlamı- Fayda/Katkı Sağlama

\begin{tabular}{lc}
\hline Kategori & Frekans \\
\hline Hayatını İdame Ettirme & 14 \\
Fayda Üretme & 12 \\
Kendini Mutlu Hissetmesi / Mutlu Eden Meşgale & 4 \\
Gelecek Kaygısının Giderilmesi & 3 \\
Kadının Güçlenmesi & 3 \\
Prestij / İtibar Oluşturma & 2 \\
Bireysel Gelişimi Sağlama & 2 \\
Hedeflerine Ulaşma & 2 \\
Bireyi Dinç Tutması & 2 \\
Hayatı Kolaylaştırma & 2 \\
Manevi Tatmin & 2 \\
İz Brrakma & 2 \\
Kendini Kanıtlama & 1 \\
Sağlı̆ı Koruma Aracı & 1 \\
Keyif Alması & 1 \\
Bireye Huzur Vermesi & 1 \\
Performansını Ortaya Koyma & 1 \\
Bireyin Özsaygısını Artırma Aracı & 1 \\
Uzman Yetiştirme & 1 \\
Kendini Geç̧ekleştirme & 1 \\
\hline Toplam Frekans & 58 \\
\hline
\end{tabular}

Tablo 1'den görüldüğü üzere öğretim üyeleri fayda/katk1 sağlama alt boyutunda, hayatlarını idame ettirmeyi $(\mathrm{n}=14)$, fayda üretmeyi $(\mathrm{n}=12)$ ve kendilerini mutlu hissetmeyi $(\mathrm{n}=4)$ çalışmanın onlara kazandırdığı fayda/katkı olarak görmektedirler. Bu konudaki bazı görüşler aşağıda verilmiştir.

"Çalışmak şöyle önemli: Bir kere geçiminizi sağlamanız lazım ama ben aynı zamanda mesleğimi de seviyorum makine mühendisliği olarak da..." (Pamukkale Üniversitesi, Mühendislik, dr. ögr. üyesi, erkek)

“... çalışmazsak bir şey, para kazanamayız” (Yüzüncü Yıl Üniversitesi, İIBF, doç. dr., erkek)

“... bir, zevk almaya çalışmak anlaşıllyor. Bir de, maddi giderlerinizin karşılanmasıdır." (Yüzüncü Yıl Üniversitesi, Tip, prof. dr., erkek) 
Tablo 2.

Çalışmanın Anlamı- Var Oluş Çabası

\begin{tabular}{lc}
\hline Kategori & Frekans \\
\hline Varlığını Ortaya Koyma & 6 \\
Çalışmanın Bireyin Hayatında Büyük Bir Yer Kaplaması & 5 \\
Çalışmanın Vazgeçilemez Olması & 4 \\
Çalışmamanın Ne Olduğunu Bilmeme & 3 \\
Hayatını Anlamlı Kılma Çabası & 1 \\
Değersizlik Hissinin Üstesinden Gelinmesi & 1 \\
\hline Toplam Frekans & 20 \\
\hline
\end{tabular}

Tablo 2'den görüldüğü üzere öğretim üyeleri, var oluş çabası alt boyutunda, çalışmanın, onların varlığını ortaya koyduğunu $(n=6)$, hayatlarında büyük bir yer kapladığını $(n=5)$ ve vazgeçilmez olduğunu $(n=4)$ belirtmişlerdir. Bu konudaki bazı görüşler aşağıda verilmiştir.

“.. çalışmak tabi akademisyen olduğumuz için bizim hayatımızın tamamı haline gelmiş. Hayatınızın tüm safhalarını ele geçirmis vaziyette. Eve gidiyoruz iş bitmiyor. Okula geliyoruz iş yetişmiyor, zaman bitiyor. Çalışmanın artık biraz hayatımızın tamamını ele geçirdiğini düşünüyorum." (Yüzüncü Yll Üniversitesi, Tıp Fakültesi, dr. öğr. üyesi, erkek)

"Çalışma olmazsa herhalde toplumda hiçbir şey olmaz. Herhalde bir anarşi, bir düzensizlik, bir kaos olurdu. Mutlaka çalışmak lazım. Vazgeçilmez." (Pamukkale Üniversitesi, Tıp Fakültesi, doç. dr., erkek)

"Çalışmayl kendim için anlamlı olan, değerli olan, kendimi bir parçası olarak hissedebileceğim bir alanda nefes alıp vermek olarak ifade edebilirim." (Pamukkale Üniversitesi, Eğitim, prof. dr., erkek)

Tablo 3.

Çalıșmanın Anlamı- İș Odaklı Olma

\begin{tabular}{lc}
\hline Kategori & Frekans \\
\hline Çalışmayı Hobi Olarak Görme & 2 \\
I̧kolik Olma & 2 \\
Alışkanlık & 1 \\
Meşgale & 1 \\
\hline Toplam Frekans & 6 \\
\hline
\end{tabular}

Tablo 3'ten görüldüğü üzere öğretim üyeleri, iş odaklı olma alt boyutunda, çalışmayı hobi olarak gördüklerini $(n=2)$ ve işkolik olduklarını $(n=2)$ ifade etmişlerdir. Bu konudaki görüşlerden biri aşağıda verilmiştir.

“.. bir hocamız vardı o söylerdi: 'Ya kitap okuyorum ve bana para veriyorlar, bu çok güzel bir şey.' derdi. Yani, aslında birçok insanın hobi olarak düşündüğü ya da hobi derken işin yanında ekstra bir farklılık, bir hoşluk olarak düşündügü̈ bir şeyi ben, iş olarak yapıyorum, bu güzel bir şey." (Ankara Üniversitesi, Siyasal Bilgiler Fakültesi, dr. ögr. üyesi, kadın)

\section{İşin anlamlı tarafları}

İşin anlamlı tarafları temasına ilişkin yanıtlar, "güçlendirme", "fayda/katkı sağlama", "işin niteliği ve bürokratik yapı" ve "öğretim ve öğretimin niteliği" olmak üzere dört kategoride toplanmaktadır. Bu kategorilere ilişkin frekanslar, çoktan aza doğru "işin niteliği ve bürokratik 
yap1 (n=64)", "güçlendirme (n=45)", "fayda/katk1 sağlama $(n=40)$ ve "öğretim ve öğretimin niteliği $(\mathrm{n}=27)$ " olarak sıralanmaktadır. İşin anlamlı tarafları temasına ilişkin kategoriler Tablo 4, Tablo 5, Tablo 6 ve Tablo 7'de verilmiştir.

Tablo 4.

İşin Anlamlı Tarafları- İşin Niteliği ve Bürokratik Yap1

\begin{tabular}{lc}
\hline Kategori & Frekans \\
\hline İdari İşlerin Angarya Olması & 11 \\
Soruşturma Yapma & 5 \\
Ders Yükünün Fazla Olması & 4 \\
Formaliteden İşler Yapma & 4 \\
Yöneticiliğin Angarya Olması & 3 \\
Bürokratik İşlerin Anlamsızlığı & 3 \\
Aşırı İş Yoğunluğu & 3 \\
Devletin Mesleği Önemsememesi & 3 \\
Merkeziyetçi Yapı & 2 \\
Şartların Yetersizliği & 2 \\
Hobi Olabilecekken İş Olarak Yapması & 2 \\
Atama- Yükseltme Kriterlerine İlişkin Sorunlar & 2 \\
İşin Sunduğu Esneklik & 2 \\
Sosyal Bilimlerin Teşviklerden Fen Bilimlerinin Yararlandığı Gibi Yararlanamaması & 1 \\
Topluma Doğrudan Katkısının Olmadığı Makaleleri Üzerinden Değerlendirilme & 1 \\
Akademik Çalışmalarda Tekrara Düşme Tereddüdü & 1 \\
Sosyal Bilimlerde Fen Bilimlerindeki Gibi Net Sonuçlar Ortaya Koyamama & 1 \\
Sürekli Çalışmanın Getirdiği Stres & 1 \\
Performans Değerlendirmenin Makale Niteliğini Düşürmesi & 1 \\
Sanayi İle İşbirliğinin Olmaması & 1 \\
Bilimsel Çalış̧aların Dikkate Alınmaması & 1 \\
Taşradaki Öğretim Üyelerinin Görüşlerinin Alınmaması & 1 \\
Eğitim Programlarının Hızlı Değişmesi & 1 \\
Doçentlikten Sonra Mesleğin Cazibesini Yitirmesi & 1 \\
Kontrol Edemediği Süreçler Olması & 1 \\
Uygulamaya Geçirilmeyenin Motivasyonu Kırmasına Neden Olması & 1 \\
Varlığının Öğrenciler İçin Anlam İfade Edip Etmediğini Bilmemesi & 1 \\
Örgütsel Desteğin Sınırlı Olması & 1 \\
Her Derste İyi Ders İşleme Çabası & 1 \\
Çalışmanın Hayatında Büyük Bir Yer Kaplaması & 1 \\
Angarya Olarak Görülenin Daha Sonra İşine Yarayacak Olması & 1 \\
\hline Toplam Frekans & 1 \\
\hline & 1 \\
\hline
\end{tabular}

Tablo 4'ten görüldüğü üzere öğretim üyeleri, işin niteliği ve bürokratik yapı alt boyutunda, idari işleri angarya olarak gördükleri $(n=11)$, soruşturma yaptıkları $(n=5)$, ders yükünü fazla buldukları $(n=4)$ ve formaliteden işler yaptıkları $(n=4)$ için yaptıkları işi anlamlı bulmayabilmektedir.Bu konudaki bazı görüşler aşağıda verilmiştir:

“... biz daha çok yolun başında olduğumuz için, asistanken de sıkça karşılaşıyorduk, nispeten azaldı hoca olduğumuzda ama yine elimize geliyor idarî işler. Artık o kadar sıkılmışız ki hani yarım saatlik iş olsa bile, bu da nereden çıktı diyorum ben şahsen." (Pamukkale Üniversitesi, İ̈BF, dr. ögr. üyesi, erkek) 
“... yardımcı personel sayımız az olduğu için onların yapabileceği işlerin bize verilmesi bende büyük zaman kayıplarına sebep oluyor." (Pamukkale Üniversitesi, Mühendislik, doç. dr., erkek)

“... İkincisi, bir akademisyenin sürekli olarak bürokrasiyle, kâğgt işleriyle, evrak işleriyle uğraştırılmast. Angarya gibi gelen bir şey. Bunun için bir akademisyenden maksimum performans alınabilmesi için -bunlar idarî personelle nasıl yapılabileceksebir takım sistem değişikliğiyle bunun üzerinden bu yükün kaldırılması lazım." (Yüzüncü Yll Üniversitesi, Mühendislik, prof. dr., erkek)

Tablo 5 .

İşin Anlamlı Tarafları- Güçlendirme

\begin{tabular}{lc}
\hline Kategori & Frekans \\
\hline İşin Sunduğu Özgürlük & 8 \\
Araştırma Yapma & 7 \\
Hasta Memnuniyetini Sağlama & 4 \\
Yabancı Literatürdeki Bulguları Türkiye'ye Uyarlama & 3 \\
Kendini Mutlu Hissetmesi & 3 \\
İki Önemli Meslek Olan Öğretmenlik Ve Hekimliğin Kesişmesi & 3 \\
İnsan Hayatı Kurtarma & 3 \\
Bilimin İlerlemesi İçin Çaba Gösterme & 3 \\
Bilgi Birikimini Paylaşma & 2 \\
Araştırma Ve Öğretimi Birlikte Yürütme Zorunluluğu & 2 \\
İşin Sunduğu Özgünlük & 1 \\
Öğrenciler İçin Rol Modeli Olma & 1 \\
Öğrencilere Problemlerini Çözmede Yardımcı Olma & 1 \\
Sosyal İlişki Kurması & 1 \\
Keşfetme & 1 \\
Takdir Hakkına Bağlı Davranış Üstlenmesinin Getirdiği İş Yükü & 1 \\
Ürün Çıkarma & 1 \\
\hline Toplam Frekans & 45 \\
\hline
\end{tabular}

Tablo 5 'ten anlaşı1dığı üzere öğretim üyeleri, güçlendirme alt boyutunda, yaptıkları iş özgürlük sunduğu $(n=8)$, araştırma yapmalarına imkân verdiği $(n=7)$ ve hasta memnuniyetini sağladığı $(n=4)$ için yaptıkları işi anlamlı bulmaktadırlar. Bu konudaki bazı görüşler aşağıda verilmiştir:

“... bu işin de bir tanımı var ama bu da belki özerklikle ilgili, hâlâ her şeye rağmen de kendi ilgi alanlarımın ve işte beklentilerim doğrultusunda bir alanda çalışabiliyorum." (Ankara Üniversitesi, Siyasal Bilgiler, dr. öğr. üyesi, kadın)

“... Bu işin en önemli kısmı benim için bilimsel yanları ama diğer kısımlar biraz vakit alıcı. Benim çalışmalarımı aksatıcı durumlara sebep olabiliyor." (Pamukkale Üniversitesi, Mühendislik, doç. dr., erkek)

Tablo 6.

İşin Anlamlı Tarafları- Fayda/Katkı Sağlama

\begin{tabular}{lc}
\hline Kategori & Frekans \\
\hline Bireysel Gelişimi Sağlama & 10 \\
Ekonomik Kaygı Hissetme & 4 \\
Fayda Üretme & 4 \\
Toplumun/Başkalarının Gelişimini Sağlama & 3 \\
\hline
\end{tabular}




\begin{tabular}{lc}
\hline Prestij/İtibar Oluşturma & 3 \\
Teorinin Uygulamaya Geçmesi & 2 \\
Manevi Tatmin & 2 \\
Bireyi Dinç/ Enerjik Tutması & 2 \\
Kendi Statüsündekilerle Arkadaşlık & 1 \\
Çocuklarını En İyi Biçimde Yetiştirmesi & 1 \\
Kendini Genç Hissetmesi & 1 \\
Yurt Diş1 Yayın Yapabilme & 1 \\
Yerel Sorunu Yabancı Literatürle Destekleme Şartı & 1 \\
Gençlerle Kurulan İletişim & 1 \\
Topluma Hizmet & 1 \\
Teorinin Uygulamaya Geçememesi & 1 \\
Öğrenciliğin Devamı Olarak Görmesi & 1 \\
Onemli Bir Meslek Sahibi Olma & 1 \\
\hline Toplam Frekans & 40 \\
\hline
\end{tabular}

Tablo 6'dan anlaşıldı̆̆ı üzere öğretim üyeleri, fayda/katk1 sağlama alt boyutunda, yaptıkları işin bireysel gelişimi sağlaması $(n=10)$, fayda üretmeyi sağlaması $(n=4)$, toplumun gelişimini sağlaması $(n=3)$ ve işin prestijli olması $(n=3)$ nedeniyle anlamlı bulduklarını ifade etmiş̧lerdir. Buna karşın öğretim üyelerinin yaptıkları işin ekonomik kaygı hissetmelerine $(n=4)$ yol açması nedeniyle öğretim üyeleri yaptıkları işi anlamlı bulmayabilmektedirler. Bu konudaki bazı görüşler aşağıda verilmiştir:

“... Hep kendinizi yeniliyorsunuz, yeni şeyler ögrenmek istiyorsanı, benim de en sevdiğim şey o." (Yüzüncü Yıl Üniversitesi, Mühendislik, dr. ögr. üyesi, erkek)

“... kendinizi geliştirebiliyorsanız, gelişiminizi görebiliyorsanız aslında çok anlamlı oluyor, takip edebiliyorsanız. Ben neredeydim, nereye geldim. Bir şeyler kattım kendime." (Yüzüncü Yll Üniversitesi, Eğitim, doç. dr., erkek)

“... Biz ise kendimize çalışıyoruz gibi geliyor bana, çünkü öğrendiğimiz her şeyin bizim kişisel gelişimimize katkısı var. Dolayısıyla başka bir meslek bu kadar insanın kendisini geliştirmesinde, farkl noktalara getirmesinde bu derece etkili olmaz diye düşünüyorum." (Pamukkale Üniversitesi, İ̈BF, prof. dr., erkek)

Tablo 7.

İşin Anlamlı Tarafları- Öğretim ve Öğretimin Niteliği

\begin{tabular}{lc}
\hline Kategori & Frekans \\
\hline Öğretim Görevinin Önemi & 11 \\
Uzman Yetiştirme & 5 \\
Öğrenci Altyapısının Zayıflığı & 3 \\
Öğrenciler Üzerinde Bir Etki Bırakabilme & 3 \\
Öğrencileri Sınav Yapma & 3 \\
Alana Katkı Getirmeyen Kongrelerin Yapılması & 1 \\
Gençlikten Beklenti İçinde Olma & 1 \\
\hline Toplam Frekans & 27 \\
\hline
\end{tabular}

Tablo 7'den görüldüğü üzere öğretim üyeleri, öğretim ve öğretimin niteliği alt boyutunda, öğretim görevinin öneminin $(n=11)$ ve uzman yetiştirme görevinin $(n=5)$ yaptıkları işi anlamlı kıldığını belirtmişlerdir. Bu konudaki bazı görüşler aşağıda verilmiştir: 
“... bazıları ders verme işini çok sevmiyorlar. Bunu daha çok bir külfet olarak görüp, bizim asıl amacımız yazmak, çizmek, araştırma yapmak diyorlar. Tabi, işin bir boyutu da bu, buna katıllyorum ama ben bir taraftan eğitimci olmayl, bir şey anlatmayı seviyorum, ders anlatmayı çok seviyorum." (Ankara Üniversitesi, Siyasal Bilgiler, dr. ögr. üyesi, kadın)

“... zaman zaman karşılaşlyoruz, hastaneye gittiğimizde, bizim öğrencilerimiz bize müdahale ediyor. Bizim ögrencilerimiz uzman olmuş, hoca olmuşlar. Tedavide yardımcı oluyorlar. Tabi bunlarl gördükçe büyük bir gurur duyuyorum." (Pamukkale Üniversitesi, Tip, doç. dr., erkek)

"Biz akademisyenlerin temel görevlerimizden biri ögretmenliktir. Bu misyonla ögrencilerin bilgisini, zihnini, karakterini veya yeteneğini geliştirmekteyiz.” (Yüzüncü Yll Üniversitesi, IIIBF, prof. dr., erkek)

\section{İşi anlamlı kılan/kılmayan örgütsel faktörler}

Öğretim üyelerinin işlerini anlamlı kılan örgütsel faktörler temasına ilişkin yanıtlar, "akademik kalite", "kişiler arası ilişkiler", "örgütsel olanaklar", "yükselme ve gelişme", "akademisyenlik mesleği", "örgütsel ortam ve yönetimi", "çalışma şartları", "mevzuat" ve "denetim" olmak üzere dokuz kategoride toplanmaktadır. Bu kategorilere ilişkin frekanslar, çoktan aza doğru "örgütsel ortam ve yönetimi $(n=41)$ ", "kişiler arası ilişkiler $(n=20) "$, "akademik kalite $(n=16) "$ ", "çalışma şartları ( $n=11)$ ", "yükselme ve gelişme $(n=9)$ " ile "akademisyenlik mesleği $(n=9)$ ", "mevzuat $(\mathrm{n}=6)$ " ve "örgütsel olanaklar $(\mathrm{n}=3)$ " ile "denetim $(\mathrm{n}=3)$ " şeklinde sıralanmaktadır. İşi anlamlı k1lan/k1lmayan örgütsel faktörler temasına ilişkin kateogoriler Tablo 8, Tablo 9, Tablo 10, Tablo 11, Tablo 12 ve Tablo 13'te verilmiştir:

Tablo 8.

İşi Anlamlı K1lan/Kılmayan Örgütsel Faktörler- Örgütsel Ortam ve Yönetimi

\begin{tabular}{lc}
\hline Kategori & Frekans \\
\hline Örgütsel Destek & 6 \\
Merkeziyetçi Yapı & 3 \\
Kurumsal Hedeflerin Olması & 3 \\
Baskı Olmaması & 3 \\
Kurumsal (Üniversite) Özerklik Olmaması & 2 \\
Örgüt Geleneği & 2 \\
Yönetimin Müdahalesi & 2 \\
Farklı Kültürlerden İnsanların Gelmesi & 1 \\
Takdir Görmeme & 1 \\
Makamın Saygı̈lı̆̆ının Olması & 1 \\
Yeni Kurulan Üniversitelerde Yaşanan Zorluklar & 1 \\
Adam Kayırmaca & 1 \\
Üniversitede Katılımcı Demokrasinin Olmaması & 1 \\
Kendini Özgürce İfade Edememe & 1 \\
Kurum Kültürünün Olmaması & 1 \\
Akademik Hiyerarşinin Olması & 1 \\
Eğitim Fakültelerini Önemsememe & 1 \\
Eğitim Fakültesi Öğretim Üyelerinin Karşı Duruş Sergileyememesi & 1 \\
Kurumsal Aidiyet Olmamas1 & 1 \\
Üniversite İle Akademisyenler Arasında Organik Bağ Olmaması & 1 \\
Bilim Adamının Özerkliğinin Olmaması & 1 \\
Keyfi Uygulamalar & 1 \\
Formaliteden İşler Yapma & 1 \\
\hline
\end{tabular}




\begin{tabular}{lc}
\hline Kolay Erişilebilir Bilgi Ağının Olmaması & 1 \\
Tüm Bireylerin Üzerine Düşeni Yapması & 1 \\
Sanayi İle İşbirliğinin Olmaması & 1 \\
Üniversite Yönetiminin Verdiği Değere Bağlı & 1 \\
Toplam Frekans & 41 \\
\hline
\end{tabular}

Tablo 8'den görüldüğü üzere öğretim üyeleri, örgütsel ortam ve yönetimi alt boyutunda, örgütsel desteği $(n=6)$, kurumsal hedeflerin olmasını $(n=3)$ ve baskı olmamasını $(n=3)$ işi anlamlı kılan örgütsel faktör olarak görmektedirler. Buna karşın öğretim üyeleri, merkeziyetçi yapıyı $(n=3)$ işi anlamlı kılmayan örgütsel yapı olarak görmektedirler. Bu konudaki bazı görüşler aşağıda verilmiştir:

"İş tatmini noktasında, anlamlandırma noktasında örgütün çok önemli olduğunu düşünüyorum sevdirme ya da uzaklaştırma açısından. Ben kendi yaşadıklarım çerçevesinde şansl olarak görüyorum kendimi. Kurumumu sevmek, öğrencilerimi sevmek, yeni konular araştırma konusunda kurumsal anlamda büyük destekler aldım." (Pamukkale Üniversitesi, İBF, prof. dr., erkek)

"Mesela yönetimsel bir problem var, özellikle kendi kurumumuzun iş ortamında. Merkeziyetçi bir yapı hâkim. Siz ne yapıyorsunuz, ne ediyorsanız muhatabınız rektör. Bir proje mi çıkaracaksınız, bir iş mi yapacaksınız, eleman mı talep ediyorsunuz, muhatabinız rektördür." (Yüzüncü Yıl Üniversitesi, Mühendislik, dr. öğr. üyesi, erkek)

“... tabi ki etkili olur yönetim dese ki işte, şu saatte gelin, laboratuarı şöyle açın, şöyle kullanın, şunu yapın, bunu yapın vs. gibi kurallar koysa tabi ki etkili olur.” (yönetimin tutumunun mutlu olma veya mutsuz olma üzerine meslekte etkisini kast ediyor) (Ankara Üniversitesi, Ĕ̈itim, dr. ögr. üyesi, kadın)

Tablo 9.

İşi Anlamlı Kılan/Kılmayan Örgütsel Faktörler- Kişiler Arası İlişkiler

\begin{tabular}{lc}
\hline Kategori & Frekans \\
\hline Kişiler Arası Pozitif İlişkiler & 3 \\
Rektörlük Seçimlerinde Gergin Ortam & 3 \\
İnsan İlişkilerinin Belirleyici Olması & 3 \\
Meslektaşlarla Yapplan Çalışmalar & 2 \\
Empati Kurmama & 2 \\
Kişiler Arası Negatif İlişkiler & 2 \\
Rol Beklentisine Uygun Davranmama & 2 \\
Çatışma Yönetimi & 1 \\
Kendi Statüsündekilerle Arkadaşlık & 1 \\
Politikacı Demeçlerinin Toplumda Yansıması & 1 \\
\hline Toplam Frekans & 20 \\
\hline
\end{tabular}

Tablo 9'dan görüldüğü üzere öğretim üyeleri, kişiler arası ilişkiler alt boyutunda, kişiler arası pozitif ilişkileri $(n=3)$ işi anlamlı kılan örgütsel faktörler olarak belirtirken, rektörlük seçimlerinde gergin ortam oluşmasını $(n=3)$ ve insan ilişkilerinin belirleyici olmasını $(n=3)$ da işi anlamlı kılmayan örgütsel faktörler olarak görmektedirler. Bu konudaki bazı görüşler aşağıda verilmiştir:

“Tip Fakültesi mensubu bir öğretim görevlisinin toplumda bir takım beklentileri karşılaması lazım. Bu beklentilerin dışına çıktı̆ıımıda davranışlarımızla, yaptıklarımızla, hastalarla ya da öğrencilerle olan ilişkilerimizde, istenmeyen ya da hoş 
olmayan davranışlarla öne çıktı̆̆ımız zaman, örgütün gölgesinde çirkin bir şey olmuş oluyor." (Pamukkale Üniversitesi, Tip, dr. ögrr. üyesi, kadın)

“... pozisyon alınmış, ataması YÖK’ten, cumhurbaşkanlı̆̆ından vs. daha farklı olduğu için gelen rektör adaylarından talepleriniz de çok daha farklı oluyor. Huzur olacak mı, daha mutlu olabilecek miyiz, insanlarla uğraşılacaklar mı gibi." (Yüzüncü Yıl Üniversitesi, Mühendislik, doç. dr., erkek)

Tablo 10.

İşi Anlamlı Kılan/Kılmayan Örgütsel Faktörler- Akademik Kalite

\begin{tabular}{lc}
\hline Kategori & Frekans \\
\hline Yayınların Niteliğinin Önemsenmemesi & 3 \\
Akademik Disiplinin Olmaması & 2 \\
Prestij/İtibar Oluşturamama & 2 \\
Öğrenci İhtiyaçlarının Karşılanmaması & 2 \\
Öğrenci Alt Yapısının Zayıflığı & 1 \\
Bilgi Birikimini Paylaşma & 1 \\
Teorinin Uygulamaya Geçmesi & 1 \\
Eğitim Fakültesi Öğretim Üyelerinin Akademik Nosyonunun Olmaması & 1 \\
Yetenek Yönetiminin Olmaması & 1 \\
Sadece Yurtdışı Dergilerde Yayının Önemsenmesi & 1 \\
Çalışmalarının Başkaları Tarafından İzlenmesi & 1 \\
\hline Toplam Frekans & 16 \\
\hline
\end{tabular}

Tablo 10'dan görüldüğü üzere öğretim üyeleri, akademik kalite alt boyutunda, yayınların niteliğinin önemsenmemesini $(n=3)$, akademik disiplinin olmamasını $(n=2)$, prestij/itibar oluşturamamayı $(n=2)$ ve öğrenci ihtiyaçlarının karşılanmamasını $(n=2)$ işi anlamlı kı1mayan örgütsel faktörler olarak görmektedirler. Bu konudaki bazı görüşler aşağıda verilmiştir:

“... benim sürekli eleştirdiğim şeyler var, isterseniz onlarl da söyleyeyim. Örneğin yapılan çalışmanın sayısından çok, niteliği benim için önemli.” (Ankara Üniversitesi, Mühendislik, doç. dr., erkek)

“... toplumda üniversitelerin saygınlı̆̆ kalmadl son yllarda. Önceden üniversiteye toplumun bakışl, "elittir bunlar" diye ama yine de sayglyla elitlik arasinda bir şeydi. Şimdi ne elitlik kaldı ne de saygı kald, 'onlar orada sırça köşklerinde otururlar'." (Pamukkale Üniversitesi, Mühendislik, prof. dr., erkek)

Öğretim üyeleri, çalışma şartları alt boyutunda, şartların yetersizliğini $(\mathrm{n}=11)$ işi anlamlı kılmayan örgütsel faktörler olarak görmektedirler. Bu konudaki bazı görüşler şöyledir:

“... maddi anlamda bizim daha iyi yaşamamızı sağlayabilen bir ortam olsa biz daha verimli çalışırız." (Pamukkale Üniversitesi, Tıp, dr. ögrr. üyesi, kadın)

“... Üniversitede yönetim o yönde kararlar alıp da araştırma yönünü kesen bir yönetim değil, o yüzden imkânlar daha çok maddi olarak düşünüyorum ben. Maddi imkânsızlıkların verdiği kalitenin azalışı söz konusu." (Yüzüncü Yıl Üniversitesi, Tıp, doç. dr., erkek)

“... hemşire az, bir türlü karşılayamıyoruz veya diyelim pahalı bir alet alacağız, çok zorluklarla, uzun sürede ancak ikna edip alabiliyoruz. Bu belki rektörlüğünde elinde 
değil, bu sefer devlete kadar gidiyor. Üniversite hastaneleri şu anda zor durumda devlet hastanelerine göre." (Ankara Üniversitesi, Tip, prof. dr., erkek)

Tablo 11

İşi Anlamlı Kılan/Kılmayan Örgütsel Faktörler- Yükselme ve Gelişme

\begin{tabular}{lc}
\hline Kategori & Frekans \\
\hline Atama- Yükseltme Kriterlerine İlişkin Sorunlar & 3 \\
Liyakat Olmaması & 1 \\
Bireysel Gelişimi Sağlama & 1 \\
Teşvik Edici Düzenlemeler & 1 \\
Akademisyenlerin İhtiyaçlarının Göz Ardı Edilmesi & 1 \\
Performans Kriterlerinin Yıldırıcı Olması & 1 \\
Akademik Ve İdari Yükselme & 1 \\
\hline Toplam Frekans & 9 \\
\hline
\end{tabular}

Tablo 11'den anlaşılacağ üzere öğretim üyeleri, yükselme ve gelişme alt boyutunda, atama-yükseltme kriterlerine ilişkin sorunları $(n=3)$ işi anlamlı kılmayan örgütsel faktörlerden görmektedirler. Bu konuyla ilgili olan bir görüş aşağıda verilmiştir:

“Türkiye'de niyeyse bu atama yükselme kriterleri genel olarak üniversitenin örgütlenmesi planlanırken, alanlara göre bir ayrım yapılmıyor; sosyal bilimler, doğa bilimleri, özellikle tıp bunlar çok farklı alanlar. Bu alanlarda akademik üretim yapmanın koşulları da çok farkll, bunlar çoğu zaman hesaplanmıyor. Çok basit bir örnek, hep doğa bilimleri ve tıp alanında daha fazla yayın yapıldığı söyleniyor. Bunu asla küçümsemiyorum ama Tip Fakültesinden altı kişi bir araya gelip yayın yapıyorlar. Bir vaka, hepsi aynı vakada çalışmış olabilir, gayet meşru bir şey. Fakat sosyal bilimler alanında iki kişinin bir araya gelip ortak bir şey yazması tek bir kişinin yazmasından daha zor, farklı kavramlar. Dolayıslyla, böyle bir şeyi hiç hesaplamıyorlar." (Ankara Üniversitesi, Siyasal Bilgiler, dr. ögr. üyesi, kadın)

Tablo 12.

İşi Anlamlı Kılan/Kılmayan Örgütsel Faktörler- Akademisyenlik Mesleği

\begin{tabular}{lc}
\hline Kategori & Frekans \\
\hline İş Güvencesinin Olmaması & 2 \\
Toplumun Önyargılı Bakışı & 1 \\
Araştırma Ve Öğretimi Birlikte Yürütme Zorunluluğu & 1 \\
İşin Sunduğu Esneklik & 1 \\
İş Yükünün Fazla Olması & 1 \\
Bilginin Dalga Dalga Yayılmasında Rol Oynama & 1 \\
Uzman Yetiştirme & 1 \\
Mesleğin Toplumdaki Statüsü & 1 \\
Toplam Frekans & 9 \\
\hline
\end{tabular}

Tablo 12'den anlaşılacağı üzere öğretim üyeleri, akademisyenlik mesleği alt boyutunda, akademisyenlerin iş güvencesinin olmamasını $(n=2)$ işi anlamlı kılmayan örgütsel faktörlerden görmektedirler. Bu konuyla ilgili olan bir görüş aşağıda verilmiştir:

“... hiçbir üniversitede, hiçbir öğretim üyesi -birkaç tane göze batan çıktı- onların dışında hiç kimse çıkıp da bir olay olduğunda bir şey yapamıyor. Çünkü iş güvenceniz bile yok. Hukuk da işe yaramıyor, iş güvenceniz de yok, dolaylslyla neme lazım diyor insanlar. Attyorlar, sürüyorlar, atamasını yapmıyorlar, yükseltmesini yapmiyorlar." (Pamukkale Üniversitesi, Mühendislik, prof. dr., erkek) 
Tablo 13.

İşi Anlamlı Kılan/Kılmayan Örgütsel Faktörler- Mevzuat

\begin{tabular}{lc}
\hline Kategori & Frekans \\
\hline Destekleyici Mevzuat & 1 \\
Mevzuatın Sürekli Değişmesi & 1 \\
Mevzuatın Sınırlandırıcı Etkisi & 1 \\
Kısıtlayıcı Kurumsal Yapı & 1 \\
Hantal Bürokratik Yapı & 1 \\
Hükümetin Sağlık Politikaları & 1 \\
\hline Toplam Frekans & 6 \\
\hline
\end{tabular}

Tablo 13’te görüldüğü üzere öğretim üyeleri, mevzuat alt boyutunda, ağırlıklı olarak mevzuatın sürekli değișmesinin, mevzuatın sınırlayıcı etkisinin, kurumsal yapının kısıtlayıcı olmasının, bürokratik yapının hantal olmasının yaptıkları işi anlamlı kılmayan örgütsel faktörler olarak görmektedirler. Bu konudaki bir görüş aşağıda verilmiştir:

“... en önemli şeylerden bir tanesi de mevzuat tabi. Daha çok işleri kolaylaştırmak için normalde olması lazım, düzene sokmak için.. Sürekli olarak mevzuatın değişmesi ve sürekli olarak sizi farklı adımlar atmaya zorlaması sizin şevkinizi kıran unsur açıkçası. Yönergeler bağlamında veya yönetmelik bağlamında bu bizim en büyük engelimiz oluyor. Bütün bunlar yapllırken de sisteme sokmak için veya düzene koymak için yapllyyor gibi geliyor ama öğretim üyesini zorlayan bir husus oluyor. Farkl değerlendirme kriterlerinin kullanılması, sürekli olarak eski ögrencilere farkl muamele yapılması, yeni ögrencilere farklı muamele yapılması.." (Yüzüncü Yıl Üniversitesi, Mühendislik, doç. dr., erkek)

Öğretim üyeleri, örgütsel olanaklar alt boyutunda, ödüllendirme sistemini $(n=3)$ işi anlamlı kılan örgütsel faktörlerden görmektedirler. Bu konudaki bir görüş aşağıda verilmiştir:

“... mail grubumuzda $H$ indeksleri yayınlaniyor, bunlar ilan ediliyor. Bu ne oluyor, $H$ indeksinde yüksek olan akademisyenler? Bir nevi olumlu olarak teşvik edilmiş oluyor, bunlar yapılabilir. Ödüller verilebilir teşvik amaçll ya da işte hocam belki A sinıfi dergilerde yayın yapanlara laptop ya da yurtdlş̧ kongreler gibi, olumlu işler yapabilir." (Yüzüncü Yıl Üniversitesi, Tip, dr. ögrr. üyesi, erkek)

Öğretim üyeleri, denetim alt boyutunda, örgütsel süreçlerin kontrol edilememesini $(n=3)$ işi anlamlı kılmayan örgütsel faktör olarak görmektedirler. Bu konudaki bir görüş aşağıda verilmiştir:

“... yukarıdan aşağlya gelen süreci kontrol edemiyoruz, o anlamda bakildiğında e ne yapıyoruz? Belki dediğim gibi, nefes alacak alanlar açıyoruz. Kontrol edemediğiniz bir sürecin de parçası olmak istemiyorsunuz, zaten olmuyorsunuz da. Yabancılaşlyorsunuz kurumsal anlamda." (Pamukkale Üniversitesi, Eğitim, prof. dr., erkek)

\section{İş-yaşam dengesi}

Denge temasına ilişkin yanıtlar; "denge/dengesizlik nedeni", "dengeyi sürdürme", "dengeleme/dengeyi kurma", "dengeyi kolaylaştırma/zorlaştırma" ve "dengesizliğin sonucu" olmak üzere beş kategoride toplanmaktadır. Bu kategorilere ilişkin frekanslar, çoktan aza doğru "dengeyi kolaylaştırma/zorlaştırma $(n=41) ", \quad$ "denge/dengesizliğin nedeni $(n=18) "$, "dengeleme/dengeyi kurma ( $n=12)$ ", "dengeyi sürdürme $(n=10)$ " ve "dengesizliğin sonucu 
$(\mathrm{n}=4)$ " şeklinde sıralanmaktadır. İş- Yaşam Dengesi temasına ilişkin kategoriler Tablo 14, Tablo 15, Tablo 16, Tablo 17 ve Tablo 18'de verilmiştir.

Tablo 14.

İş-Yaşam Dengesi- Dengeyi Kolaylaştırma/Zorlaştırma

\begin{tabular}{lc}
\hline Kategori & Frekans \\
\hline İş Yoğunluğunun Denge Kurmayı Zorlaştırması & 5 \\
İşin Hayatında Yer Kaplamasından Dolayı Dengenin İş Dışı Yaşam Aleyhine & 4 \\
Bozulması & \\
Geleneksel Aile Yaşantısının Denge Kurmayı Zorlaştırması & 3 \\
Eşi De Akademisyen Olanlarda Denge Kurmanın Zorlaşması & 3 \\
Bürokratik İşlerin Denge Kurmayı Zorlaştırması & 1 \\
Acil Durumlarda Eve İş Götürmek Zorunda Olması & 2 \\
Çocuk Olduğunda Dengenin Çocuk Aleyhine Bozulması & 2 \\
Başarı İçin Dengenin Aile Aleyhine Kurulması Gerektiği & 2 \\
Şehir Dşında Doktora Yapmanın Denge Kurmayı Zorlaştırması & 2 \\
Dengeyi Kurmakta Zorlanmanın Kaynağını Bilememe & 1 \\
Anlayışlı Bir Eşe Sahip Olmanın Denge Unsuru Olması & 1 \\
Aynı Meslekten Eşe Sahip Olmanın Denge Unsuru Olması & 1 \\
Yöneticilikte İş- İş Dışı Yaşam Dengesinin Kurulabilmesi & 1 \\
Akademik Çevreden Arkadaşlı Yapmanın Dengeyi Kolaylaştırması & 1 \\
Mesleğin Feminizasyonunun Dengeye Etkisi & 1 \\
Süreli İşlerin Dengeyi Kurmayı Zorlaştırması & 1 \\
İş Yoğunluğuna Alışması & 1 \\
Fen Bilimleri Ve Tıpta Esnekliğin Olamayabileceği & 1 \\
Sadece Rutin İşlerin Eve Taşınmasının İş-İş Dışı Yaşam Dengesini Sağlayabilmesi & 1 \\
Denge Kurmaya Çalışırken Eşin Üzerine Yük Binmesi & 1 \\
Araştırma Görevlisinin Denge Kurmasının Danışmana Bağlı Olması & 1 \\
Doktora Yapıyor Olmanın Denge Kurmayı Zorlaştırması & 1 \\
Başka İlçeye Derse Gitmenin Denge Kurmayı Zorlaştırması & 1 \\
Yükselme Kaygısına Bağlı Olarak Çok Çalışmanın Denge Kurmayı Zorlaştırması & 1 \\
Mesai Olmamasının Denge Kurmayı Zorlaştırması & 1 \\
Çocuk Olduğunda Dengenin İş̧ Aleyhine Bozulması & 1 \\
Toplam Frekans & 41 \\
\hline
\end{tabular}

Tablo 14'ten anlaşıldığı üzere öğretim üyeleri, dengeyi kolaylaştırma/zorlaştırma alt boyutunda, iş yoğunluğunun denge kurmayı zorlaştırdığını $(\mathrm{n}=5)$, işin öğretim üyelerinin hayatında yer kaplamasından dolayı dengenin iş dışı yaşam aleyhine bozulduğunu $(n=4)$, geleneksel aile yaşantısının denge kurmayı zorlaştırdığını $(n=3)$ ve eşi de akademisyen olanların denge kurmada zorlandıklarını $(\mathrm{n}=3)$ belirtmişlerdir. $\mathrm{Bu}$ konudaki bazı görüşler aşağıda verilmiştir:

"Çalı̧̧ma şartları anlamında biz şu birkaç yıldır çok yoğun değiliz ikinci öğretimlerimiz kapand. Öncesinde hem normal öğretim, hem gece öğretiminde öğrenci sayllarımız çok fazlaydı. Benim de bir kızım var, ben mesela dört beş sene öncesi neredeyse iki günden fazla çocuğumu hiç görmedim. Sabah 8'de dersim vard, çocuğum uyuyordu, akşam 11 'de eve gidiyordum çocuğum yine uyuyordu. Ertesi sabah 8'de yine dersim var, yine uykuda. Gece tekrar öyle, böyle günler illaki yaşadık bu anlamda sıkıntı. Çocuğumuzdan vakit çaldık $m$, eşimden çaldım mi, çaldım. Hala çallyor muyuz, tabi çallyoruz." (Pamukkale Üniversitesi, Ĕgitim, dr. ögr. üyesi, kadın) 
“... tam denge kurduğumu söylersem yalan olur. Kuramadı̆̆ım zamanlar ağırlıkta oluyor. İş daha ağır basıyor. Mesela şu an itibariyle işte yaptığım iki tane proje var, vaktimin çoğunu allyor." (Pamukkale Üniversitesi, Mühendislik, doç. dr., erkek)

Tablo 15.

İş- Yaşam Dengesi- Denge/Dengesizliğin Nedeni

\begin{tabular}{lc}
\hline Kategori & Frekans \\
\hline Dengenin Bireyin Kendisine Bağlı Olması & 6 \\
Dinamik Dengelerin Olması & 3 \\
Yaşadığı İlin Olumlu Şartlarının Denge Unsuru Olması & 2 \\
Çalışma Esnekliğinin Yönetime/Denge Kurmanın Yöneticiye Bağlı Olması & 2 \\
Olumlu Şartların Denge Unsuru Olması & 1 \\
Akademisyenliğin Çatışma Potansiyelini Barındırması & 1 \\
Takdir Hakkına Bağlı Davranış Üstlenmesinin İşinin Bitmesini Engellemesi & 1 \\
Gurbette Olmanın Aile Bağlarını Güçlendirmesi & 1 \\
Evlilikte Aynı Kültürden Olmanın Denge Unsuru Olması & 1 \\
\hline Toplam Frekans & 18 \\
\hline
\end{tabular}

Tablo 15'ten görüleceği üzere öğretim üyeleri, denge/dengesizliğin nedeni alt boyutunda, dengenin bireyin kendisine bağlı olduğunu $(n=6)$ ve fakültelerinde dinamik dengelerin olduğunu $(\mathrm{n}=3)$ belirtmişlerdir. Bu konudaki bazı görüşler aşağıda verilmiştir:

"Burada bir eğitim göreviniz var, bir araştırma göreviniz var, varsa bir de sanayi ile ilgili etkileşimli yürüttüğünüz projeler var. Bunlar zamanında aksatmadan yürütebildiğiniz sürece bana göre kalan zamanınızla ilgili tasarruf size verilmiş durumda." (Ankara Üniversitesi, Mühendislik, dr. ögretim üyesi, erkek)

"Denge kurma artık bireysel yeteneğinize bağll. Tabi aşırıya da kaçmamak lazım. Çok da vazgeçemiyorsunuz." (Pamukkale Üniversitesi, Tip, doç. dr., erkek)

"Onu da dengeleyebilmek kişisel, bazı arkadaşlarımız daha iyi dengeleyebiliyor, bazı arkadaşlarımız dengeleyemiyor." (Yüzüncü Yıl Üniversitesi, Eğitim, prof. dr., erkek)

Tablo 16.

İş- Yaşam Dengesi- Dengeleme/Dengeyi Kurma

\begin{tabular}{lc}
\hline Kategori & Frekans \\
\hline Meslekte İlk Yıllarda Dengenin Kurulamaması & 4 \\
Doçentlikle Birlikte Dengenin Kurulması & 3 \\
Uyku Saatinden Kısmanın Denge Unsuru Olması & 2 \\
Zamanın Denge Unsuru Olması & 1 \\
Aile Birliğinin Korunmasına Yönelik Politikalar Geliştirilmesinin Dengeyi Kurması & 1 \\
Rol Bilincine Sahip Olmanın Denge Unsuru Olması & 1 \\
\hline Toplam Frekans & 12 \\
\hline
\end{tabular}

Tablo 16'dan görüldüğü üzere öğretim üyeleri, dengeleme/dengeyi kurma alt boyutunda, mesleğin ilk yıllarında dengenin kurulamadığını $(n=4)$; bununla birlikte doçentlikle birlikte dengenin kurulduğunu $(\mathrm{n}=3)$ ifade etmişlerdir. Bu konudaki bazı görüşler şunlardır:

“... doktora yapıyorum ve 183 dakika filan uyuduğumu hatırlyyorum. O süre içerisinde günlük 183 dakikayla idare etmek zorundayım çünkü işe geliyorum, işleri yetişstirmem lazım, üstüne araştırma yapıp..” (Ankara Üniversitesi, Eğitim, dr. öğr. üyesi, kadın) 
“... başta hiç sağlamadl, tamamiyla çalışma odaklı bir hayatım oldu ve diğer her şey buna göre şekillendi." (Ankara Üniversitesi, Siyasal Bilgiler, doç. dr., kadin)

“... önce dengeyi kuramamıştım, daha çok işti.” (Pamukkale Üniversitesi, Mühendislik, prof. dr., erkek)

Tablo 17.

İş-Yaşam Dengesi- Dengeyi Sürdürme

\begin{tabular}{lc}
\hline Kategori & Frekans \\
\hline İşin Sunduğu Esnekliğin Denge Unsuru Olması & 3 \\
Çalışan Sayısının Denge Unsuru Olması & 2 \\
Bekâr Olmanın Denge Kurma Sorunu Yaratmaması & 2 \\
Evde Sözünün Dinlenir Olmasının Denge Kurmayı Sağlaması & 1 \\
Çocukları Karşılaştırarak Dengeye İlişkin Fikir Sahibi Olması & 1 \\
Planlamayla Dengenin Kurulabilmesi & 1 \\
\hline Toplam Frekans & 10 \\
\hline
\end{tabular}

Tablo 17'den anlaşılacağı üzere öğretim üyeleri, dengeyi sürdürme alt boyutunda, işin sunduğu esnekliğin denge unsuru olduğunu $(n=3)$, çalışan sayısının denge unsuru olduğunu $(n=2)$ ve bekâr olmanın denge kurma sorunu yaratmadığını $(n=2)$ belirtmişlerdir. Bu konudaki bir görüş aşağıda verilmiştir:

“... okulda çalıştı̆̆ım gibi evimde de aynı işi yapmaya devam ediyorum ya da normalde bazen akademik faaliyeti bulmam gereken zamanlarda ise ailevi faaliyetlerde bulunabiliyorum, bu meslek bana o imkânı veriyor rahatlıkla." (Yüzüncü Yıl Üniversitesi, Mühendislik, dr. ögr r. üyesi, erkek)

Tablo 18

İş- Yaşam Dengesi- Dengesizliğin Sonucu

\begin{tabular}{lc}
\hline Kategori & Frekans \\
\hline Dengeyi Kuramamanın Boşanmayla Sonuçlanması & 1 \\
Dengeyi Kurmaya Çalışırken Bocalama & 1 \\
Eve İş Taşımanın Yaşam Biçimi Olması & 1 \\
Dengeyi Kurmaya Çalışırken Ortalama Çalışmalar Çıkarma & 1 \\
\hline Toplam Frekans & 4
\end{tabular}

Tablo 18 'den görüldüğü üzere öğretim üyeleri, dengesizliğin sonucu alt boyutunda, dengeyi kuramamanın boşanmayla sonuçlandığını, öğretim üyelerinin dengeyi kurmaya çalışırken bocaladığını, eve iş taşımanın yaşam biçimi olduğunu ve dengeyi kurmaya çalışırken ortalama nitelikte çalışmaların ortaya çıktığını ifade etmişlerdir. Bu konudaki bir görüş aşağıda verilmiștir:

"Dengeyi işe ağırlık veriyoruz ister istemez. Ki biliyorsunuz zaten işte doktora yaparken eski eşimle asıl boşanmamızın neden bu yani." (Ankara Üniversitesi, Eğitim, dr. öğr. Üyesi, kadin)

\section{İşin bireyin kendisine ve başkalarına katkı sağlaması}

Katkı temasına ilișkin yanıtlar, "bireye katkı", "örgüte katkı" ve "başkalarına katk1" olmak üzere üç kategoride toplanmaktadır. Bu kategorilerin frekansları çoktan aza doğru "başkalarına katkı $(\mathrm{n}=60)$ ", "bireye katkı $(\mathrm{n}=56)$ " ve "örgüte katkıda $(\mathrm{n}=5)$ " olarak sıralanmaktadır. İşin bireyin kendisine ve başkalarına katkı sağlaması temasına ilişkin kategoriler Tablo 19, Tablo 20 ve Tablo 21'de verilmiştir. 
Tablo 19.

İşin Bireyin Kendisine ve Başkalarına Katkı Sağlaması- Başkalarına Katkı

\begin{tabular}{|c|c|}
\hline Kategori & Frekans \\
\hline Çevresine Danışmanlık Yapması & 7 \\
\hline Bilgi Birikimini Paylaşması & 6 \\
\hline Ailesinin Söz Konusu Olduğu Durumlarda Fedakârlıkta Bulunma & 4 \\
\hline Uzman Yetiştirme & 3 \\
\hline Problem Çözme & 3 \\
\hline Çocuklarını En İyi Biçimde Yetiştirmesi & 3 \\
\hline Türk Kadınını Temsil Etme & 2 \\
\hline Ücretli Danışmanlık Hizmeti Vermesi & 2 \\
\hline Yakınlarının Kendisiyle Gurur Duyması & 2 \\
\hline İnsanların Memnuniyetini Sağlama & 2 \\
\hline Aileleri Yönlendirmesi & 2 \\
\hline Toplum Üzerinde Etki Bırakabilme & 2 \\
\hline Çalışmalarının Başkaları Tarafından İzlenmesi & 1 \\
\hline Öğretmenleri İnformal Yoldan Bilgilendirme & 1 \\
\hline Ailesindeki Çocukların Bilinçlenmesini Sağlama & 1 \\
\hline Öğretmenler İle Pozitif İlişkiler Geliştirme & 1 \\
\hline Aile İçi İletişimi Sağlama & 1 \\
\hline Ailesine Zaman Ayıramaması (Ailesine Katkısının Olmaması) & 1 \\
\hline Eğitim Konusunda Ailesini Güdülemesi & 1 \\
\hline Öğrenciler Üzerinde Etki Bırakabilme & 1 \\
\hline Gençlere Eleştirel Düşünmeyi Öğretme Çabası & 1 \\
\hline Öğretmesi & 1 \\
\hline Türkiye'yi Temsil Etme & 1 \\
\hline Ailesine Zaman Ayırabilmesi & 1 \\
\hline Öğrenciler İçin Rol Modeli Olma & 1 \\
\hline Çocuklarının Bilinçlenmesini Sağlama & 1 \\
\hline İz Bırakma & 1 \\
\hline Problemi Çözmesi Sonucu Ürün Oluşturması & 1 \\
\hline Eşin Çalışmalarına Katkı Getirmesi & 1 \\
\hline Tartışma Kültürünü Besleyen Çalışmalar Yapma & 1 \\
\hline Sanayi İle İşbirliği Sonucu Ekonomik Katkı Sağlama & 1 \\
\hline Topluma Hizmet Çalışmalarında Bulunması & 1 \\
\hline Öğrenci Gelişimini Sağlama & 1 \\
\hline Hastalıkların Teşhisi & 1 \\
\hline Toplam Frekans & 60 \\
\hline
\end{tabular}

Tablo 19'dan görüldüğü üzere öğretim üyeleri, başkalarına katk1 alt boyutunda, çevrelerine danışmanlık yaptıklarını $(n=7)$, bilgi birikimlerini paylaştıklarını $(n=6)$ ve aileleri söz konusu olduğu durumlarda fedakârlıkta bulunduklarını $(n=4)$ ifade etmişlerdir. Bu konudaki bazı görüşler aşağıda verilmiştir:

“... genellikle bir danışma makamı olarak bir konuma gelmiş durumdayım aile arasında ya da akrabalarda. Bu konuda ya da eğitim konusunda herhangi bir bilgi sahibi olmak isteyen ilk başvuracă̆l kişi ailede ben oluyorum." (Yüzüncü Yll Üniversitesi, Mühendislik, dr. ögretim üyesi, erkek)

“... Lisans döneminde bu dersi öğrenirken çok zorlanmıştım (Farmakoloji'yi kast ediyor), bir şekilde ilaç isimlerini ezberlemek, onların içindeki etken maddesinden tutun da komplikasyonları, endikasyonları, yan etkileri filan aklinda tutup bir de onlar 
aktarmak zorunda olmak... Ama şimdi akademik unvana sahip olduktan sonra bunların bir yolu olduğunu öğrendim. Bu yolları çözdükçe öğrencilerin -kendi lisans döneminde yaşadığım zorlukları bildiğim için- daha kolay aşabilecekleri yöntemler geliştirmeye çalıştım." (Yüzüncü Yıl Üniversitesi, Tıp, doç. dr., erkek)

“... benden bir şey istedikleri zaman bazen çok yoğun olabiliyorum ama benim ona hayır deme hakkım yok. Bu bilgiyi bunun için ediniyorum. Dolaylsiyla bana bir dergide "şu konuda bize bir şey yazar misinız?" dediklerinde bunu "yazamam" deme hakkın kendimde bulmuyorum. Çünkü 30 yıl boyunca bu bilgileri bunlar için edinmişim. Peki, yapmasam ne olacak? Benim kafamda bu bilgilerin hepsi, benimle beraber, benimle beraber de gidecek. Bir yere aktarmak gerekiyor bunları. Dolayısıyla, yayın yapmak, kitap yazmak ondan sonra bu bilgiyi çıktı olarak ortaya koymamı gerekiyor." (Ankara Üniversitesi, Siyasal Bilgiler, prof. dr., kadin)

Tablo 20.

İşin Bireyin Kendisine ve Başkalarına Katkı Sağlamas1- Bireye Katkı

\begin{tabular}{lc}
\hline Kategori & Frekans \\
\hline Kendini Mutlu Hissetmesi & 11 \\
Prestij/İtibar Oluşturma & 9 \\
Bireysel Gelişme Sağlaması & 8 \\
Ekonomik İhtiyaçlarını Karşılamasi/Hayatını İdame Ettirmesi/Ekonomik Getiri & 4 \\
Manevi Tatmin & 3 \\
İşin Sunduğu Özgürlük & 2 \\
Bireyin Özgüvenini Artırma & 2 \\
Bireyi Dinç Tutması & 2 \\
İşin Sunduğu Özerklik & 2 \\
Tanınırlık & 1 \\
Kişiler Arası Pozitif İlişkiler Geliştirme & 1 \\
Kendini Gerçekleştirme & 1 \\
Kendini Genç Hissetmesi & 1 \\
Yüksek Gelir Sağlama & 1 \\
Takdir Hakkını Kullanabilmesi & 1 \\
İhtiyaçlarını Karşılayabilmesi & 1 \\
Eğlenmesi & 1 \\
İstediğini Gerçekleştirmiş Olması & 1 \\
Kendisiyle Gurur Duyması & 1 \\
Empati Kurabilme Becerisi Kazanma & 1 \\
Objektif Olabilme Becerisi Kazanma & 1 \\
Bireyin Bilgilerini Güncellemesi & 1 \\
\hline Toplam Frekans & 56 \\
\hline
\end{tabular}

Tablo 20'den anlaşılacağı üzere öğretim üyeleri, bireye katkı alt boyutunda, kendilerini mutlu hissettiklerini $(n=11)$, prestij/itibar sahibi olduklarını $(n=9)$ ve bireysel gelişmeyi sağladıklarını $(\mathrm{n}=8)$ ifade etmişlerdir. Bu konudaki bazı görüşler şöyledir:

“En büyük artısı benim mutluluğum, en önemlisi o.” (Pamukkale Üniversitesi, İIBF, dr. ögretim üyesi, erkek)

“... ben sevdiğim işi yapıyorum yani beni tatmin etmiş oluyor, beni mutlu ediyor.

Faydası bu şekilde." (Pamukkale Üniversitesi, Mühendislik, doç. dr., erkek) 
“... ben çok mutluyum öğretim üyesi olduğumdan dolayl. Bir şeye hizmet verebileceksem bu şey altında verebilirim. Öğretim üyeliğinin böyle bir ayricalı̆̆ var bence. İyi ki olmuş diyorum." (Ankara Üniversitesi, Mühendislik, prof. dr., erkek)

Tablo 21.

İşin Bireyin Kendisine ve Başkalarına Katkı Sağlaması- Örgüte Katk1

\begin{tabular}{lc}
\hline Kategori & Frekans \\
\hline Bilimin İlerlemesine Katkıda Bulunma & 2 \\
Kendi Coğrafyasının Özelliklerini Tanıtması & 1 \\
Teorinin Uygulamaya Geçmesini Sağlama & 1 \\
Bölüm Standartlarını Yükseltme Çabası & 1 \\
\hline Toplam Frekans & 5 \\
\hline
\end{tabular}

Tablo 21'den görüldüğü üzere öğretim üyeleri, örgüte katk1 alt boyutunda, bilimin ilerlemesine katkıda bulunduklarını $(\mathrm{n}=2)$ ifade etmişlerdir. Bu konudaki bir görüş aşağıda verilmiştir:

"Ayrıca gerçekleştirdiğimiz araştırmalarla bilimin ilerlemesine yani insanlığın ilerlemesi ve gelişmesine katkı sağlamaktayız." (Yüzüncü Yıl Üniversitesi, IIIBF, prof. dr., erkek)

\section{Tartışma, Sonuç ve Öneriler}

Bulgulara göre öğretim üyeleri için çalışmak-iş yapmak, hayatı idame ettirme anlamına gelmektedir. Öğretim üyeleri, bireyin geçimini sağlama, para kazanma, ailesinin ihtiyaçlarını karşılama açılarından çalışmanın önemine dikkat çekmektedirler. Öte yandan Harpaz'ın (1990) yöneticiler, memurlar, özel sektör hizmet ve üretim işlerinde çalışanlar üzerinde yaptığ araştırma sonucunda, çalışanlar, psikolojik ve güvenlik ihtiyaçları gibi daha düşük düzeydeki ihtiyaçlardan doyum sağladıklarında, ekonomik ödüllerin çok da önemli olmadığı bulunmuştur. $\mathrm{Bu}$ gruplar içerisinde özellikle yüksek ödeme alan yöneticilerin, ödemenin önemine daha az değer biçtikleri saptanmıştır. Yapılan işin ilginç olması, özerklik, yükselme gibi çalışmanın anlamlı yönleri yöneticileri motive ettiği için malî ödüller ikinci planda kalmaktadır. Görece yüksek ödeme alan profesörler için çalışma, sadece hayatlarını idame ettirmenin bir aracı değil; varlıklarını ortaya koymanın da bir aracıdır. Bu bulguyla paralellik gösteren Miller'ın (2008) araştırma sonucuna göre de en çok 60'lı yaşlardaki kişilerin, anlamlı işin dört boyutunu birden tam anlamı ile deneyimlediği, işe ilişkin birleşmiş bütünlük duygusunu (integrated wholeness) hissettikleri bulunmuştur. Bu bulgular, akademik kariyerin son basamağına gelmiş profesörlerin birleşmiş bütünlük duygusunu yaşadıkları sonucuna götürebilir. Kariyerinin henüz başında olan akademisyenler ise ekseriyetle psikolojik sözleşmelerinin ihlal edildiği algısına sahip oldukları için örgütlerarası ve uluslararası kariyer hamlesi yapma arayışı içerisindedir. Bu noktada genç akademisyenlerin birleşmiş bütünlük duygusunu hissetmedikleri söylenebilir (Baruch ve Fidan, 2019). Diğer yandan iş ve kimlik arasındaki ilişki, kişinin işi ile kurduğu ilişkinin niteliğine göre şekillenebilmektedir. İş, insana verdiği benlik duygusuyla, belki de kişinin kimliğinin oluşumundaki en temel öğedir (Wieland, Bauer ve Deetz, 2009, Akt. Lair ve Wieland, 2012). $\mathrm{Bu}$ açıdan da mesleğinde uzun süre geçiren bir çalışan olarak profesörün, işiyle bireysel kimliğinin bütünleşmiş olması olasıllı̆g yüksektir.

Unvandan bağımsız olarak öğretim üyelerine göre bireysel gelişimi sağlama ve öğretim işlevi, görece öğretim üyeliği işinin en anlamlı tarafları iken; idarî işler işin anlamlı olmayan taraflarını ifade etmektedir. Iqbal ve Mahmood'un (2011) idarî kadro ve öğretim üyeleri üzerinde yaptıkları bir araştırmaya göre akademik görevlerin yanında yönetsel görevlerin yürütülmesinin, düşük araştırma verimliliğine neden olduğu tespit edilmiştir. Sevindi'ye (2013) göre düşük verimlilik, tükenmişliğin sonuçlarındandır. Duygusal tükenmişliği yaşayanlar ise çoğunlukla yönetsel göreve sahip akademisyenlerdir. Bu kapsamda öğretim üyelerinin işlerini, 
mesleklerini daha üst düzeyde anlamlı bulabilmeleri, kendilerini işlerine tam olarak verebilmeleri için öncelikle angarya olarak algıladıkları idarî nitelikteki bazı etkinlikler (yazışmalar, nöbetler, komisyon üyeliği, soruşturma yapma vs.) görece azaltılmalıdır. Bu doğrultuda üniversitelerde idarî görevleri yerine getirecek çalışan sayısının arttırılması önerilebilir.

Katılımcılardan doktor öğretim üyelerine göre öğretim üyeliği işinin sunduğu özgürlük, işin anlamlı taraflarındandır. Bu bulgu, Morin, Tonelli ve Pliopas'ın (2007) işin anlamı üzerine yaptıkları araştırmada, özerklik ve görevin doğasının, "anlamlı iş"in temel değerleri olduğu bulgusuyla örtüşmektedir. Benzer olarak Bowie (1998) de kişiye özerklik ve bağımsızlık deneyimi sağlamanın, anlamlı işin önemli özelliklerinden biri olduğunu belirtmiştir. Öte yandan doçentlere göre araştırma yapma, işin anlamlı taraflarındandır. Bu bulgular, öğretim üyelerinin öğretim üyeliği işinin felsefesi, işlem, eylem ve etkinliklerinden memnun oldukları; bu işten bireysel ve meslekî doyum sağladıkları sonucuna götürebilir. Anlamlı iş yaşantısına sahip olmanın iş doyumu ile ilişkili olduğu alanyazında da belirtilmiştir (Barsh, Cranston ve Craske, 2008; Bunderson ve Thompson, 2009).

Öğretim üyelerine göre öğretim üyeliği işinin görece en önemsiz ya da anlamsız taraflarından biri, şartların yetersizliğidir. Bu çerçevede doçentler örgütsel desteği, işi anlamlı kılan faktörlerden biri olarak görmektedirler. Özellikle tıp fakültesi öğretim üyeleri, Devletin, üniversite hastanelerine yeterli kaynak aktarmamasının neden olduğu olumsuz fizikî koşullara, tıbbî araç- gereç temin edememe gibi durumlara işaret etmişlerdir. Benzer biçimde diğer fakültelerin öğretim üyeleri, yayın ve proje yapabilme ve yurtdışında misafir öğretim üyesi olarak görev yapabilme konusunda gerekli maddî kaynak sağlanmaması sınırlılığından söz etmişlerdir. Fiziksel şartların yetersizliği, Doğan'ın (2013) ortaya koyduğu gibi sadece 2006 yılından sonra kurulan üniversitelerde değil; araştırmanın çalışma grubunu oluşturan görece kurumsallaşmış ya da kurumsallaşmakta olan üniversitelerin de önemli bir sorunudur. $\mathrm{Bu}$ nedenle öğretim üyelerinin işlerinde verimli olmaları ve doyum sağlamaları dolayısıyla işlerini anlamlı bulmaları için YÖK, TÜBİTAK ve üniversite yönetimlerinin işbirliği yaparak gerekli kaynakları sağlaması önemlidir.

Katılımcıların unvan ayırımı gözetilmeksizin tümüne göre iş yoğunluğu, iş-yaşam dengesini kurmayı zorlaştırmaktadır. Öğretim üyelerinin; uyku saatlerinden kısarak, akademik çevreden arkadaşlıklar kurarak, rutin işleri eve taşıyarak, aynı meslekten eş ile evlenerek işleri ile yaşamları arasında dengeyi kurmaya çalıştıkları bulgusuna ulaşılmıştır. Bu bulgu, öğretim üyelerinin iş-iş dışı yaşam dengesini kurmalarının, büyük ölçüde bireyin kendisine bağlı olduğu sonucuna götürebilir. Bu sonuç, Miller'ın (2008) anlamlı iş konusunda alanyazına kazandırdığı "dengesizlik duygusu (sense of imbalance)" kavramı ile (anlamlı görülmeyen işin, bireysel yaşamda dengesizlik yaratabileceği olgusu) örtüşmektedir. Gmelch ve Burns'e (1993) göre zaman baskıs1, meslektaşlarla karşı karşıya kalma, örgütsel kısıtlamalar ve fakülte görevleri, bölüm başkanlığı yapan öğretim üyelerinin işlerini zorlaştıran, iş yüklerini arttıran faktörlerdir. Ağır iş yükünün öğretim üyelerini strese soktuğuna ilişkin araştırma bulgularına rastlanmıştır (Gmelch ve Burns, 1993; Johnson, 1993). Benzer şekilde ağır ya da gereksiz iş yükünün, akademisyenlerin işlerinden kaynaklanan içsel doyumu aşındırabileceğine ilişkin araştırma bulguları vardır (Soliman ve Soliman, 1997). İş yükünün dışında Caproni'ye (1997) göre mükemmellik tutkusu, yapılan seçimlerle hayat üzerinde kontrolü sağlama yaklaşımı ve değerler, kişilerin iş-yaşam dengesi kurmasında engelleyici olabilen etkenlerdir. Kişinin bu yapılara bağlı olarak iş-yaşam dengesi kurabilmesi, öncelikleri ve değerleri konusunda bireysel farkındalık geliştirebilmesine bağlıdır. Esnek çalışma koşulları, özünde, öğretim üyelerinin iradeleri ve istekleri doğrultusunda meslekî görevde bulunmalarını sağlamaktadır (Baruch ve Hall, 2004). Esnek çalışma saatlerinin öğretim üyelerine sağladığı özgürlüğün, onların iş-iş dışı yaşam dengelerini sürdürmelerine imkân vermesi büyük ölçüde gerçekçi iken öğretim üyelerinin işlerini nasıl yapacaklarına karar vermelerinin pratikte çok da geçerli olmadığı bir durumdur. Lucas'a (2011) göre iş ve özel yaşam arasında bir tercih söz konusu olduğunda özel yaşam ve aile ağırlık kazanmaktadır. Bu da iş kimliği ile bireysel-sosyal kimlikler arasında denge sağlamanın yaşamda sorunlu bir alana işaret eder nitelikte olduğunu göstermektedir. 
Öğretim üyeliğinin; araştırma, öğretim faaliyetleri ve topluma hizmet çalışmaları ile bireyin kendisine ve diğer insanların yaşamlarına katkı sağlayan en önemli mesleklerden biri olduğu açıktır. Öğretim üyeleri; okuma, yazma, inceleme, araştırma, bilgi edinme ve aktarma gibi iş etkinlikleriyle, kendine, yakınlarına, kurumlara ve topluma katkı sağlama duygusunu yaşama olanağına sahiptir. Öğretim üyeleri, yaptıkları işten dolayı kendilerini mutlu hissettikleri, bunun öğretim üyeliğinin sağladığı görece en önemli bireysel katkı olduğunu belirtmektedirler. Buna ek olarak doktor öğretim üyeleri, yakın çevrelerine informal danışmanlık yaparak, doçentler ile profesörler de bilgi birikimlerini paylaşarak başkalarına katkı sunmakta olduklarını belirtmektedirler. Kurtz, Kees ve Tokar'ın (2004) yaptıkları araştırmada, profesörlerin, yayın yapma motivasyonlarının kendilerine en önemli katkıyı getirdiğini belirtmeleri bu araştırmanın bulgusuyla paralellik göstermektedir. Bulgulara göre öğretim üyelerinin başkalarına sağladığı katkılar/faydalar arasında; çevresindekilere üniversite tercihi, hukuki sorunlar, sağlık, zemin ve temel etüdü vb. konularda danışmanlık yapması gelmektedir. Öğretim üyeliğinin; öğretim üyelerine diğer kişilere, gruplara, örgüte ve çevreye ayırt edici, fark yaratıc1 etkinlik ve katkılar sunduğu bulgusu, Robin'in (1998), Chalofsky'nin (2003), Miller'in (2008) ve Rulle ve Chalofsky'nin (2000) bulgularıyla da örtüşmektedir.

Öğretim üyelerinin yaptıkları işi anlamlı k1lan faktörlerin belirlenmesi, onların işdoyumunu sağlayan ve tükenmişliğine neden olan durumların ortaya konulmasını sağlayabilir. Buna ek olarak öğretim üyelerininin kendilerine ve çevrelerine sundukları katkının bilinmesi, onların kariyer gelişimlerinin nasıl destekleneceği konusunda yol gösterici olabilir. $\mathrm{Bu}$ açımlayıcı araştırmayı takiben, üniversite öğretim üyelerinin işlerini anlamlı bulmaları ile kariyer gelişimi, moral ve motivasyonları, verimlilikleri gibi değişkenler arası ilişkilerin araştırılması önerilebilir. Benzeri bir araştırma, vakıf üniversiteleri öğretim üyeleri üzerinde de yapılabilir.

\section{Kaynaklar}

Apaydın, Ç. (2012). The workload of faculty members: The example of educational faculties in Turkey. College Student Journal, 46, 203-213.

Arnold, K. A., Turner, N., Barling, J., Kelloway, E. K. ve McKee, M. C. (2007). Transformational leadership and psychological well-being: the mediating role of meaningful work. Journal of Occupational Health Psychology, 12(3), 193.

Barsh, J., Cranston, S. ve Craske, R. A. (2008). Centered leadership: How talented women thrive. Mc Kinsey Quarterly, 8, 35-48.

Baruch, Y. ve Hall, D. T. (2004). The academic career: a model for future careers in other sectors? Journal of Vocational Behavior, 64(2), 241-262.

Baruch, Y. ve Fidan, T. (2019). The Turkish academic labor market as an ecosystem. T. Fidan (Yay. Haz.) Vocational identity and career construction in education, içinde (ss. 37-57). US: IGI Global.

Beldağ, A., Yaylacı, A. F., Gök, E. ve İpek, C. (2015). Topluma hizmet uygulamaları dersinin üniversite-toplum işbirliği açısından değerlendirilmesi. Ahi Evran Üniversitesi Kırşehir Ĕ̈itim Fakültesi Dergisi, 16(2), 161-178.

Bowie, N. E. (1998). A kantian theory of meaningful work. Journal of Business Ethics, 17(910), 1083-1092.

Bozkurt, S. (2012). Örgütsel demokrasiyi ve akademik özgürlüğ̈ benimseme ve Türkiye'de uygulanabilir bulma düzeyine ilişkin öğretim elemanlarının görüşleri (Yayımlanmamış doktora tezi). Ankara Üniversitesi Eğitim Bilimleri Enstitüsü, Ankara.

Brown, A., Kitchell, M., O’Neill, T., Lockliear, J., Vosler, A., Kubek, D. ve Dale, L. (2001). Identifying meaning and perceived level of satisfaction within the context of work. Work, 16, 219-226.

Bunderson, J. S. ve Thompson, J. A. (2009). The call of the wild: Zookeepers, callings, and the double - edged sword of deeply meaningful work. Administrative Science Quarterly, $54,32-57$. 
Caproni, P. J. (1997). Work-life balance: You can't get there from here. Journal of Applied Behavioral Science, 33(1), 46-56.

Chalofsky, N. (2003). An emerging construct for meaningful work. Human Resources Development International, 6(1), 69-83.

Chalofsky, N. ve Krishna, V. (2009). Meaningfulness, commitment, and engagement: The intersection of a deeper level of intrinsic motivation. Developing Human Resources, 11, 189-203.

Chalofsky, N. E. (2010). Meaningful workplaces: Reframing how and where we work. San Francisco: John Wiley \& Sons, Inc.

Csikszentmihalyi, M. (2001). Flow: The psychology of optimal experience. New York: Harper \& Row.

Darling, J. ve Chalofsky, N. (2004). Spirituality in the workplace. M. Marquardt (Yay. Haz.) Encyclopedia of life support systems (EOLSS), içinde (ss. 124-141). Oxford, UK:EOLSS.

Doğan, D. (2013). Yeni kurulan üniversitelerin sorunları ve çözüm önerileri. Yükseköğretim ve Bilim Dergisi, 3(2), 108-116.

England, G. W. ve Whitley, W. T. (1990). Cross national meaning of working. A. P. Breif veW. R. Nord (Yay. Haz.) Meaning of Occupational work: A Collection of Essay, içinde (ss. 65-106), Lexington: M. A. Lexington Books.

Erat, S., Erdil, O., Kitapçı, H. ve Çömlek, O. (2012). The effect of the perception of organizational trust and organizational support on intention to quit and individual performance: An empirical study of the Turkish state universities. African Journal of Business Management, 6(30), 8853-8861.

Ergöl, Ş., Koç, G., Eroğlu, K. ve Taşkın, L. (2012). Türkiye'de kadın araştırma görevlilerinin ev ve iş yaşamlarında karşılaştıkları güçlükler. Yüksekögretim ve Bilim Dergisi, 2(1), 4349.

Fang, Li, F. ve Devos, P. (2008). Talent management: Art or science? The invisible mechanicm between talent and talent factory (Working paper). University of Kalmar, Sweden.

Gedikoğlu, T. (2013). Yükseköğretimde akademik özgürlük. Yükseköğretim ve Bilim Dergisi, $3(3), 179-183$.

Gmelch, W. H. ve Burns, J. S. (1993). The cost of academic leadership: Department chair stress. Innovative Higher Education, 17(4), 259-270.

Graber, D. R. ve Johnson, J. A. (2001). Spirituality and healthcare organizations. Journal of Healthcare Management, 46(1), 39-52.

Harpaz, I. (1990). The importance of work goals: An international perspective. Journal of International Business Studies, 21(1), 75-93.

Iqbal, M. Z. ve Mahmood, A. (2011). Factors related to low research productivity at higher education level. Asian Social Science, 7(2), 188-193.

Johnson, T. (1993, February). An overview of the issues surrounding faculty burnout [Öz]. Annual Convention of the Western States Communication Association'da sunulan bildiri, Albuquerque, New Mexico. Erişim adresi: https://files.eric.ed.gov/fulltext /ED369373.pdf

Kahraman, Ü. ve Çelik, K. (2015, Mayıs). Akademisyenlerin iş-aile yükleri ile iş-aile çatışmaları arasındaki ilişsi [Öz]. Eğitim Yönetimi 10. Ulusal Kongresi'nde sunulan bildiri. Gaziantep Üniversitesi, Gaziantep. Erişim adresi: http://higheredusci.beun.edu.tr/pdf/pdf_HIG_1804.pdf

Kasalak, G. ve Bilgin Aksu, M. (2014). The relationship between perceived organizational support and organizational cynicism of research assistants. Educational Sciences: Theory \& Practice, 14(1), 125-133.

Kurtz, D. L., Kees, J. ve Tokar, T. (2004). An examination of intrinsic and extrinsic motivational factors that affect research productivity of marketing academicians. Journal for Advancement of Marketing Education, 4, 9-15. 
Lair, D. J. ve Wieland, S. M. B. (2012). What are you going to do with that major? Colloquial speech and the meanings of work and education. Management Communication Quarterly, 26, 423-452.

Lip- Wierissima, M. ve Morris, L. (2009). Discriminating between "meaningful work" and "management of meaning". Journal of Business Ethics. 88, 491-511.

Lucas, K. (2011). Blue-collar discourses of workplace dignity: Using outgroup comparisons to construct positive identities. Management Communication Quarterly, 25, 353-374.

Luecke, R. (2009). En iyi elemanı işe almak ve elde tutmak. Ö. Sarıkaya (Çev.). İstanbul: İş Bankası Bankası Kültür Yayınları.

Mat, N., Romli, R., Mat, N. ve Noor, N. M. (2012). Modelling workplace spirituality and teaching effectiveness for academician in Malaysia. International Journal of Business and Management Studies, 4(1), 157-164.

May, D. R., Gilson, R. L. ve Harter, L. M. (2004). The psychological conditions of meaningfulness, safety and availability and the engagement of the human spirit at work. Journal of Occupational and Organizational Psychology, 77, 11-37.

McClure, J. ve Brown, J. M. (2008). Belonging at work. Human Resource Development International, 11(1), 3-17.

Miller, C. S. (2008). Meaningful work over the life course (Unpublished Doctoral Thesis). Fielding Graduate University, USA.

Mohan, D. L. ve Uys, K. (2006). Towards living with meaning and purpose: spiritual perspectives of people at work. Journal of Industrial Psychology, 2006, 32(1), 53-59.

Morin, E., Tonelli, M. J. ve Pliopas, A. L. V. (2007). O trabalho e seus sentidos. Psicologia \& Sociedade, 19(1), 47-56.

Mustafayeva, L. ve Bayraktaroğlu, S. (2014). İş-aile çatışmaları ve yaşam tatmini arasındaki ilişki: Türkiye ve İngiltere'deki akademisyenlerin karşılaştııılması. İşletme Bilimi Dergisi, 2(1), 127-145.

Negiz, N. ve Tokmakçı, E. (2011). Çalışma yaşamında kadının tükenmişliği: Aile-iş-sosyal yaşam açısından tükenmişlik (Süleymen Demirel Üniversitesi örneği). Journal of Yaşar University, 24(6), 4041-4070.

Öztan, E. ve Doğan, S. N. (2015). Akademinin cinsiyeti: Yıldız Teknik Üniversitesi örneği üzerinden üniversite ve toplumsal cinsiyet. Çalışma ve Toplum, 3, 191-221.

Öztürk, S. (2006). Üniversitelerin yapısal ve işlevsel değişiminde üniversite özerkliğinin yeniden tanımlanması veya özerklik kavramı ve üniversite özekliği. Üniversite ve Toplum, 6(4). Erişim adresi: http://www.universite-toplum.org/text.php3?id=287

Poyraz, B. (2013). Akademi kadınların cenneti mi? Ankara Üniversitesi örneği. Ankara Üniversitesi Sosyal Bilimler Enstitüsü Dergisi, 4(2), 1-18.

Robin, C. S. (1998). Existential perspectives on meaningful work: Explorations with executive men (Unpublished doctoral thesis). The Fielding Institute, USA.

Ros, M., Schwartz, S. H. ve Surkiss, S. (1999). Basic individual values work values, and the meaning of work. Applied Psychology: An International Review, 48(1), 49-71.

Rosso, B. D., Dekas, H. G. ve Wrzesniewski., A. (2010). On the meaning of work: A theoretical integration and review. Research in Organizational Behavior, 30, 91-127

Rulle, M. S. ve Chalofsky, N. (2000). Employee perceptions of the meaning of empowerment. K. P. Kuchinke (Yay. Haz.) Academy of Human Resource Development Conference Proceedings, içinde (ss. 70-77). Raleigh-Durham, North Carolina: Academy of Human Resource Development (AHRD).

Sevindi, T. (2013). The relationship between general self-efficacy belief and burnout level among Turkish academicians. Educational Research and Reviews, 8(24), 2255-2259.

Shenton, A. K. (2004). Strategies for ensuring trustworthiness in qualitative research projects. Education for Information, 22, 63-75.

Soliman, I. ve Soliman, H. (1997). Academic workload and quality. Assessment \& Evaluation in Higher Education, 22(2), 135-157.

Terez, T. (2000). 22 keys to creating a meaningful workplace. Holbrook, MA: Adams Media. 
Toptaş, B. (2016). Ankara ili kamu ilkokullarında görev yapan ögretmenlerin işlerini anlamlı bulma düzeyleri (Yayımlanmamış yüksek lisans tezi). Ankara Üniversitesi Eğitim Bilimleri Enstitüsü, Ankara.

Treadgold, R. J. (1997). Engagement in meaningful work: Its relationship to stress, depression, and clarity of self- concept. Dissertation Abstracts International: Section B: The Sciences and Engineering, 57(11), 7219.

Yücel, N. ve Atlı, Y. (2014). Üniversite eğitiminde üniversite-sanayi işbirliğinin önemi: Furat üniversitesi öğretim elemanları üzerine bir alan araştırması. Süleyman Demirel Üniversitesi Iktisadi ve İdari Bilimler Fakültesi Dergisi, 19(3), 153-168.

\section{Extended Abstract}

\section{Introduction}

The job has a significant role during the human life. Then, the modern person spends most of his/her time of the typical day in his job. In this context, an individual hopes the job he does to cover his/her personal values, provide the opportunity to the realization of the meaning that he attributes, provide balance between his working life and private life, provide supplement and benefit to him and the others. An individual finds his job meaningful at the rate of the realization of these expectations in his job. Bowie $(1998,1083)$ who bases the basis of meaningful work conception upon the philosophy and ethical theories, states that the meaningful work includes six basic characteristics in the framework of the writings about ethics of Kant. These are as in below:

- Being obtained freely,

- Making live the feeling of freedom and self-rule to the worker,

- Developing the capacity of worker,

- Providing sufficient income for the physical prosperity to the worker,

- Supporting morale development of the worker,

- Making feel the happiness that he wants to get in the direction of his own conceptualizing to the worker being not to paternalistic.

According to the literature, a meaningful relation exists among meaningful job and job satisfaction, motivation, communication, organizational commitment.In this framework, the aim of this research is to determine to what are the organizational factors that make the academicians' jobs meaningful and why they find them meaningful.

In the direction of this aim, the answers of the questions below are searched:

1. To what extent do the lecturers find their jobs meaningful in the perception of themselves in the job, "the understanding of the job itself", "balance understanding" and "support understanding" sub-dimensions of meaningful job?

2. What are the organizational factors making the jobs meaningful for the lecturers? Why do these factors make their jobs meaningful?

\section{Method}

In this study, qualitative research was used. The study group of the research includes lecturers (assistant professor, associate professor and professor) working in the Medical, Engineering, Economic and Administrative Sciences and Education Faculties of three public universities one of which institutionalized to a great extent [Ankara University], the other one is relatively in the middle of institutionalization process [Van Yüzüncü Y1l University], and the other one is relatively at the beginning of institutionalization process [Pamukkale University].

The data required by the qualitative research collected by "Meaningful Job Interview Form" developed by the researchers. The interview form and its content were primarily analyzed by the project team in the direction of content and expression, and then was presented to the expert views. At last, by interviewing with two lecturers, its functionality was examined. According to the results, the form has its last form. The opinions of lecturers regarding what 
makes their jobs meaningful and why in the context of qualitative research with the analysis of the data collected by a semi-structured interview form. The data collection techniques of research enable the qualitative data in the context of data triangulation. In the data of qualitative research of the research, the content analysis technique was used.

\section{Result and Discussion}

According to the qualitative research findings, lecturers-participants find the four dimensions of the meaningful job in this priority order.

- Support understanding,

- The understanding of job itself,

- Perception of himself in the job,

- Balance understanding.

The views of the participants related to the importance of job-work in qualitative research, views about the value that they give-perception of himself/herself in a job providing benefit/supplement, focus on a job, and existence effort are in the first three categories. The subcategory/code, which has the most frequency in "providing benefit/supplement category", is "constancy of life", the sub-category/ code which has the most frequency in "focus on a job category" is "putting working instead of hobby and being workaholic". The sub-category/code, which has the most frequency in "efforts for the existence" is "the manifestation of the existence".

The participants find their current jobs meaningful in four categories such as "reinforcement", "providing benefit/ supplement", "the quality of the job and the bureaucratic structure" and "education and the quality of the education" in a priority order.

In a priority order, the participants state the organizational factors which make their jobs meaningful as "academic quality", "relations among individuals", "organizational opportunities", "advancement and development", "being an academician", "organizational environment and development", "working conditions", "legislation" and "auditing". The priority order of these categories according to their frequencies are; "organizational environment and development", "relations among individuals", "academic quality", "working conditions", "advancement and development", "being an academician", "legislation", "organizational opportunities" and "auditing".

The views of the participants related to the degree of providing job-life balance in their jobs is categorized in five categories such as "reason of balance/unbalance", "constancy of balance", "redress the balance", easing/ complicating the balance", and "result of the unbalance". The priority order of these categories from much to less is; easing/ complicating the balance", "reason of balance/unbalance", "redress the balance", "constancy of balance" and "result of the unbalance".

The participants have three categories for their jobs according to its providing benefit to themselves and the others as "benefit for individual", "benefit for the organization", and "benefit for the others". This category, from much to less, be determined as "benefit for the others", "benefit for individual" and "benefit for the organization". 